\title{
Analysis of Climate Change Impacts on Tree Species of the Eastern US: Results of DISTRIB-II Modeling
}

\author{
Louis R. Iverson ${ }^{1} * * \mathbb{D}$, Matthew P. Peters ${ }^{1}$, Anantha M. Prasad ${ }^{1}$ and Stephen N. Matthews ${ }^{1,2}$ \\ 1 USDA Forest Service, Northern Research Station, Northern Institute of Applied Climate Science, Delaware, \\ OH 43015, USA; matthewpeters@fs.fed.us (M.P.P.); aprasad@fs.fed.us (A.M.P.); \\ matthews.204@osu.edu (S.N.M.) \\ 2 School of Environment and Natural Resources, The Ohio State University, Columbus, OH 43210, USA \\ * Correspondence: liverson@fs.fed.us; Tel.: +1-740-368-0097
}

Received: 22 February 2019; Accepted: 27 March 2019; Published: 2 April 2019

\begin{abstract}
Forests across the globe are faced with a rapidly changing climate and an enhanced understanding of how these changing conditions may impact these vital resources is needed. Our approach is to use DISTRIB-II, an updated version of the Random Forest DISTRIB model, to model 125 tree species individually from the eastern United States to quantify potential current and future habitat responses under two Representative Concentration Pathways (RCP 8.5 -high emissions which is our current trajectory and RCP 4.5 -lower emissions by implementing energy conservation) and three climate models. Climate change could have large impacts on suitable habitat for tree species in the eastern United States, especially under a high emissions trajectory. On average, of the 125 species, approximately 88 species would gain and 26 species would lose at least $10 \%$ of their suitable habitat. The projected change in the center of gravity for each species distribution (i.e., mean center) between current and future habitat moves generally northeast, with 81 species habitat centers potentially moving over $100 \mathrm{~km}$ under RCP 8.5. Collectively, our results suggest that many species will experience less pressure in tracking their suitable habitats under a path of lower greenhouse gas emissions.
\end{abstract}

Keywords: climate change; tree species suitable habitat; random forest model; DISTRIB-II; eastern United States

\section{Introduction}

The climate is changing, globally becoming warmer almost every year in recent decades. Risks associated with this warming are high, sometimes manifesting into multiple, broad threats to humanity [1] and the economy [2]. The recent Intergovernmental Panel on Climate Change (IPCC) report on the impacts of global warming of $1.5^{\circ} \mathrm{C}$ above pre-industrial levels, and in comparison to impacts of $2.0^{\circ} \mathrm{C}$, describes many 'Reasons for Concern' related to efforts to strengthen the global response to the threat of climate change, sustainable development, and efforts to eradicate poverty [3]. Even so, with current pledges in the Paris Agreement on Climate Change, $\sim 2.6-3.2^{\circ} \mathrm{C}$ of warming is projected by 2100 , though the Agreement aims to limit global warming "well below $2{ }^{\circ} \mathrm{C}$ " and to "pursue efforts" to limit temperatures above pre-industrial levels to $1.5^{\circ} \mathrm{C}$ [4]. The biodiversity implications of these various levels of warming are huge, as outlined in Warren, et al. [5], where climatically determined geographic range losses exceeding $50 \%$ were projected for $44 \%, 16 \%$, and $8 \%$ of plants by 2100 , corresponding to warming of $3.2,2.0$, and $1.5{ }^{\circ} \mathrm{C}$, respectively. Even though climatically determined range losses do not equate with actual distributions of plants because trees live a long time while harboring great genetic diversity, the potential effects of climate change on the biota 
of the planet are staggering. Meanwhile, the co-benefits of limiting the amount of warming towards the $1.5^{\circ} \mathrm{C}$ path are immense.

As a consequence of the range of these potential changes, models are needed to provide a suite of possible outcomes, by species, to assist decision makers to minimize biological impacts and to adapt to the coming changes. Adaptation planning has been accelerating, whether by motivation or mandate. For example, the Northern Institute of Applied Climate Science (NIACS), associated with the USDA Forest Service, has facilitated nearly 300 adaptation demonstrations or projects on forest lands over the last 10 years in the north central and northeastern United States via their Adaptation Workbook [6], www.forestadaptation.org. Model outputs are critical for understanding vulnerability and evaluating possible adaptation avenues, particularly when considering transitional or facilitated outcomes [7-9].

To arrive at reliable and informative models of how tree species may respond to a rapidly changing climate, a diverse and dynamic field has emerged, where continued refinement affords new insights. Statistical models and mechanistic models form a dichotomy of how one approaches predicting future change and each has their strengths and weaknesses $[10,11]$. Demography approaches add another useful dimension to modeling potential futures [12,13], as do paleoecologic studies [14,15]. Hybrid approaches, which use a combination of modeling methods, may also provide key insights not otherwise uncovered [16-19]. Nonetheless, primary themes from all modeling studies indicate the value of forests in the overall climate equation and the high potential for eventual forest composition and productivity changes in the future $[20,21]$.

With passing time, the evidence is mounting that changes are indeed occurring in forest composition and productivity. Evidence of migration of tree species along elevational gradients (up or down) has been mounting for some time, along with the ecological explanations for such movements [22-30]. However, latitudinal or longitudinal changes in species range are more difficult to document because of wide distributions, limited sample size, and confounding disturbance factors, such as insect pests and succession following harvest, forest clearing, fire exclusion, human introductions, or other disturbance [21,31-34]. Nonetheless, recent studies conducted with repeated inventory and demography data do provide insights into changes (or not) in range limits. Boisvert-Marsh and others [35,36] found poleward shifts in Quebec, Canada for Acer saccharum Marshal, Acer rubrum L., Fagus grandifolia Ehrh., and Betula alleghaniensis Britt. between 1970-1977 and 2003-2014, mostly attributed to warming of early- or late-season climatic variables. However, they also detected southward shifts of Abies balsamea (L.) Mill., Picea glauca (Moench) Voss, and Picea mariana (Mill.) B.S.P., attributed to natural and human disturbances. Sittaro et al. [37], also in working in Quebec, found that the spatial velocity of temperature at range limits exceeded the pace of tree species migration by a factor of two for 14 of 16 species. Woodall and D'Amato [38], in a decadal evaluation of 20 eastern US tree species not extending north of the Canada border, found stability for $85 \%$ of the species, regardless of the level of canopy disturbance.

Our modeling approach has been to statistically model potential changes in suitable habitat for a large number to species using Forest Inventory and Analysis (FIA) data and environmental co-variates. This approach has evolved along with concomitant large advances in hardware, data, analytical software, and techniques. Our first effort for 80 common trees used county-level data and the statistical technique Regression Tree Analysis [39,40]. We then moved to a $20 \times 20 \mathrm{~km}$ grid, 134 tree species, and the Random Forest technique [41-43], our original DISTRIB model which modeled suitable habitat for 134 tree species from the Eastern United States. These models were the basis for several NIACS reports on the vulnerability of forests to climate change in the Mid-Atlantic region [44], the Central Appalachians [45], the Central Hardwoods [46], the Northwoods of Minnesota [47], Michigan [48], and Wisconsin [49], New York and New England [50], and the Chicago Wilderness region [51]. Most recently, we have developed a new set of models based on newer FIA data (www.fia.fs.fed.us), higher resolution soils data [52], and a hybrid lattice composed of $10 \times 10 \mathrm{~km}$ and $20 \times 20 \mathrm{~km}$ grids, derived from FIA plot density and described in a subsequent paper. The objective of this paper is to summarize the outputs from the DISTRIB-II model, for 125 species of trees in the eastern United States. 


\section{Materials and Methods}

In our effort reported here, we present summaries from our recent revision of the original DISTRIB model, now called DISTRIB-II. The extent of our analysis encompasses the United States east of the 100th meridian. In DISTRIB-II, we developed a hybrid lattice of a mix of $20 \times 20$ and $10 \times 10 \mathrm{~km}$ cells. The mixture of cell sizes allowed us to optimize modeling by increasing resolution for those cells which had support from sufficient FIA plots. Locations, such as large parts of the Corn Belt in the Midwest, had few FIA plots, so we retained the coarser, 20-km structure, while those locations with higher densities of FIA plots were evaluated and modeled via a $10-\mathrm{km}$ structure. DISTRIB-II also used completely updated data sets of 45 environmental variables and FIA plot data; it also used newer techniques to assign model output values.

\subsection{Data}

Climate data. We used a range of models and scenarios to capture projections of future temperature and precipitation. Data included current (1981-2010) annual and seasonal mean temperature $\left({ }^{\circ} \mathrm{C}\right)$ and annual and seasonal precipitation totals $(\mathrm{mm})$ based on Parameter-elevation Regressions on Independent Slopes Model, [53] (PRISM), and end of the century (2070-2099) projected mean values from three General Circulation Models (GCM) under the 4.5 and 8.5 Representative Concentration Pathways (RCP). Downscaled future projections were obtained from NASA Earth Exchange U.S. Downscaled Climate Projections (NEX-US-DCP30) project (https://cds.nccs.nasa. gov/nex/), with metadata found at (https://cds.nccs.nasa.gov/wp-content/uploads/2014/04/NEXDCP30_Tech_Note_v0.pdf) [54]. These data are derived from GCM runs under the Coupled Model Inter-comparison Project Phase 5 (CMIP5) in support of the IPCC Fifth Assessment Report (IPCC AR5). The NEX US-DCP30 dataset was downscaled to $30 \times 30$ arcseconds via Bias-Correction Spatial Disaggregation (BCSD) [55]. Future values were derived by adjusting PRISM data with the change (the deltas) between GCM-simulated data for periods 1981-2010 and 2070-2099, similar to methods described by Monahan, et al. [56]. These delta adjustments provided closer alignment to current conditions now and minimized exposure to pixel-level artifacts between training and projection climate data. For climate summaries reported in Table 1, data were aggregated to 10-km across 41,681 cells across the eastern U.S. Three models were used, each with RCP 4.5 and 8.5 [57]: Community Climate System Model, or CCSM4 (hereafter CCSM45 and CCSM85) [58], Geophysical Fluid Dynamics Laboratory (Donner), or GFDL-CM3 (GFDL45 and GFDL85) [59], and Hadley Global Environment Model-Earth System [60] (or HadGEM2-ES (Had45 and Had85) [61]. These climate models and RCPs capture, for the entire eastern U.S. study area, a wide distribution space in projected change (Figure 1 and detailed in Table 1). Further, the mean change across these combinations (Figure 1), fall along a strong temperature gradient, from an estimated annual temperature increase of $2.5^{\circ} \mathrm{C}$ with CCSM45 to $6.5^{\circ} \mathrm{C}$ with Had85, and with an overall mean increase of $4.5^{\circ} \mathrm{C}$. The potential change in annual precipitation (though precipitation changes have higher uncertainty as compared to temperature changes) was higher for all scenarios by end of the century, but for many locations, a reduction in future precipitation is forecasted (i.e., points below the horizontal 0 change line), especially for Had85 and GFDL85 (Figure 1). Coupled with higher temperatures, especially these scenarios will likely inflict additional physiological stress on organisms for some future periods (see also [62]). This trend is especially true when examining growing season temperatures, which reach $28.4{ }^{\circ} \mathrm{C}$, an increase of $6.8^{\circ} \mathrm{C}$, for both GFDL85 and Had85. To make matters worse for plant growth, the Hadley model (Had45 and Had85) showed growing season precipitation decreases by end of the century, even though annual precipitation was slightly higher (Table 1). 


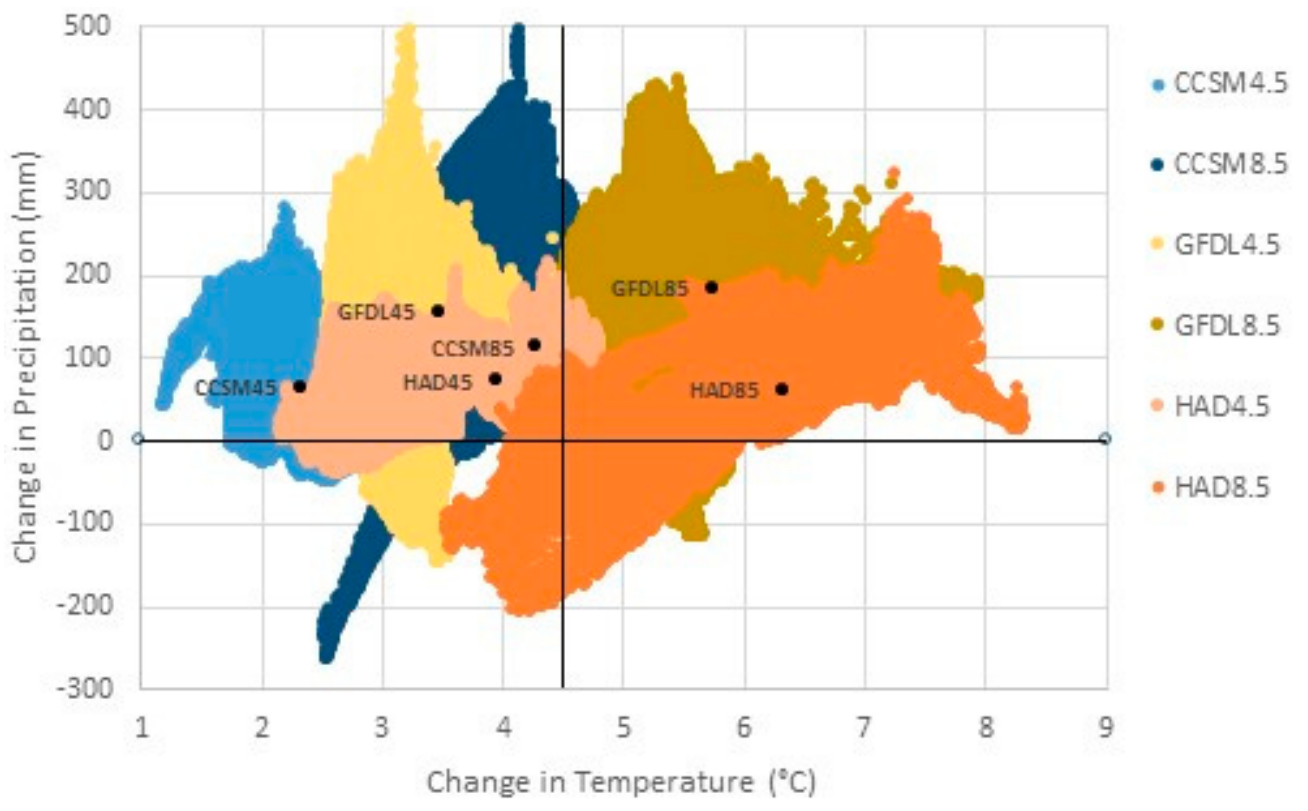

Figure 1. Distribution of annual temperature and precipitation changes from a baseline period (1981-2010) as modeled by the NASA Earth Exchange U.S. Downscaled Climate Projections (NEX-US-DCP30) data for 2070-2099, for 41,683 10-km cells across the eastern US. Black dots are the mean change in precipitation and temperature for each General Circulation Models (GCM)Representative Concentration Pathways (RCP) scenario.

Table 1. Average climate conditions in the eastern US currently and for three models (CCSM4, GFDL CM3, and HadGEM2-ES) for the 4.5 and 8.5 RCPs. CCSM4: Community Climate System Model; GFDL CM3: Geophysical Fluid Dynamics Laboratory Coupled Model 3; HadGEM2-ES: Hadley Global Environment Model-Earth System; PANN: Mean Annual Precipitation; Pgrow: Precipitation in growing season; TANN: Mean Annual Temperature; Tgrow: Temperature during growing season (May-Sept); TSUMavg: Mean Temperature of Warmest Month; TWINavg: Mean Temperature in Coldest Month; TMin: Absolute Minimum Temperature; TMax: Absolute Maximum Temperature; RCP: Representative Concentration Pathway.

\begin{tabular}{cccccccc}
\hline Variable & \multicolumn{3}{c}{ CCSM4 } & \multicolumn{3}{c}{ GFDL CM3 } & \multicolumn{3}{c}{ HadGEM2-ES } \\
\hline & Current & RCP 4.5 & RCP 8.5 & RCP 4.5 & RCP 8.5 & RCP 4.5 & RCP 8.5 \\
\hline PANN $(\mathrm{mm})$ & 1048 & 1113 & 1162 & 1203 & 1233 & 1121 & 1110 \\
Pgrow $(\mathrm{mm})$ & 509 & 527 & 519 & 573 & 585 & 504 & 457 \\
TANN $\left({ }^{\circ} \mathrm{C}\right)$ & 12.7 & 15.2 & 17.1 & 16.3 & 18.6 & 16.8 & 19.2 \\
Tgrow $\left({ }^{\circ} \mathrm{C}\right)$ & 21.6 & 24.0 & 26.3 & 26.0 & 28.4 & 25.7 & 28.4 \\
TSUMavg $\left({ }^{\circ} \mathrm{C}\right)$ & 24.8 & 26.6 & 28.1 & 28.1 & 29.7 & 28.0 & 29.9 \\
TWINavg $\left({ }^{\circ} \mathrm{C}\right)$ & -0.9 & 1.2 & 2.1 & 1.6 & 2.0 & 1.3 & 3.3 \\
TMin $\left({ }^{\circ} \mathrm{C}\right)$ & -11.3 & -8.6 & -6.5 & -7.2 & -5.7 & -7.4 & -4.0 \\
TMax $\left({ }^{\circ} \mathrm{C}\right)$ & 33.8 & 35.9 & 39.3 & 39.1 & 42.5 & 38.5 & 41.9 \\
\hline
\end{tabular}

Tree Data. As done in the earlier effort [42], we used U.S. Forest Service Forest Inventory and Analysis (FIA, www.fia.fs.fed.us) data to derive individual tree species importance values (IV) for each of 84,204 FIA plots. All plots were included with no filtering. The assumption was if the species already grows there, it can grow there. The relative number of stems and relative basal area for each species were weighted equally to calculate IV for each plot. Thus, some species with large numbers of smaller stems (e.g., Ulmus, Acer, Fraxinus spp.) may be calculated as more important than species with fewer, but larger stems (e.g., some Quercus). All 84,204 annualized FIA records sampled during the period 2000-2016 were processed, and aggregated to cells with native resolutions of either $10 \times 10 \mathrm{~km}$ or $20 \times 20 \mathrm{~km}$ to represent the mean IV within the grid cell. We strove to increase spatial resolution, 
over that of our previous effort, where the FIA data would support it; to that end, a hybrid lattice was generated through an iterative algorithm to determine whether resolution could be increased to $10 \times 10 \mathrm{~km}$ (four cells within each $20 \times 20 \mathrm{~km}$ cell), or maintained at $20 \times 20 \mathrm{~km}$. To do so, a $10-\mathrm{km}$ was accepted if $\geq 50 \%$ of the four $10-\mathrm{km}$ cells within a $20-\mathrm{km}$ cell contained two or more FIA plots, otherwise the focal $20-\mathrm{km}$ cell was retained. The resulting hybrid lattice for the eastern U.S. had 29,357 cells, $84.7 \%$ of which were comprised of $10 \times 10 \mathrm{~km}$ cells, and accounting for 2.49 million $\mathrm{km}^{2}$, or $58 \%$ of the eastern U.S. (Figure 2). The $20 \times 20 \mathrm{~km}$ cells occupied 1.79 million $\mathrm{km}^{2}$, or $42 \%$ of the area, and were mostly confined to highly agricultural areas, predominantly in the western portion of the eastern U.S. (Figure 2). To minimize species that have too few samples to build a respectable model, species were only included if they had at least 60 grid cells with at least two FIA plots per cell. This filter resulted in a total of 125 species in the analysis.

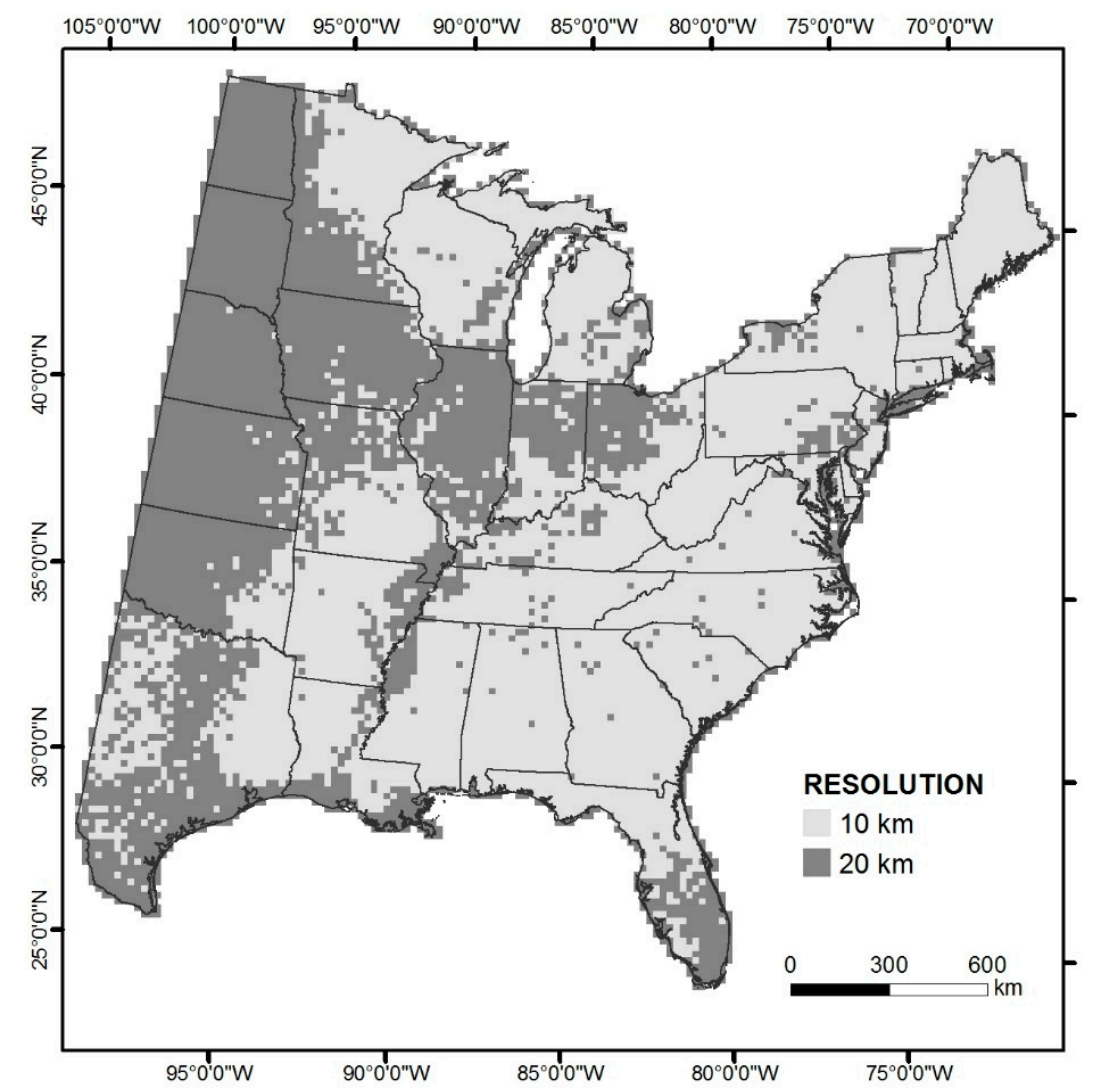

Figure 2. Extent of $20 \mathrm{~km}$ vs. $10 \mathrm{~km}$ cells used for DISTRIB-II modeling.

Environmental Data. A suite of 45 environmental variables was used to predict IV, for 125 species across the entire eastern US. We used seven climate-related variables, seven elevation-related variables, a solar-related variation of day length variable, nine soil taxonomic orders, and 21 variables related to soil properties to derive the Random Forest models [41] predicting current species IV (Table 2). These data were acquired from various sources, with most soils information from gSURRGO [52], elevation data from the shuttle radar topography mission [63], a model of solar radiation via latitude [64], and a model of soil productivity based on soil taxonomy [65]. We then swapped the seven climate-related variables with future (2070-2099) projections of the same variables according to each of the six GCM/RCP combinations (see above), and Random Forest predicted future IVs for each species. It is important to note that we are not using elevation variables as a proxy for climate-we use them to discriminate among species that prefer lower elevation habitats (for example along the coastal plains or swamps) from those that prefer more elevated habitats with rugged terrain. Also, in addition to 
improving model fit, the numerous soil variables help restrain the models' response under future climates and distinguish among species that are mostly climate driven vs. those that are less so.

Table 2. Environmental data used to predict habitat suitability of eastern U.S. tree species. Data was either aggregated to 10 and $20 \mathrm{~km}$ grids or derived from aggregated data.

\begin{tabular}{|c|c|c|c|}
\hline Category & Variable & Description & Native Resolution \\
\hline \multirow{7}{*}{ Climate $^{1}$} & Annual precipitation & $\begin{array}{l}\text { Mean 30-year (1981-2010) monthly } \\
\text { precipitation (mm). }\end{array}$ & \multirow{6}{*}{$800 \mathrm{~m}$} \\
\hline & May-Sept. precipitation & $\begin{array}{l}\text { Mean 30-year (1981-2010) monthly } \\
\text { precipitation for May-September (mm). }\end{array}$ & \\
\hline & Annual mean temperature & $\begin{array}{l}\text { Mean 30-year (1981-2010) monthly } \\
\text { temperature }\left({ }^{\circ} \mathrm{C}\right) .\end{array}$ & \\
\hline & $\begin{array}{l}\text { May-Sept. mean } \\
\text { temperature }\end{array}$ & $\begin{array}{l}\text { Mean 30-year (1981-2010) monthly } \\
\text { temperature for May-September }\left({ }^{\circ} \mathrm{C}\right) \text {. }\end{array}$ & \\
\hline & $\begin{array}{l}\text { Mean temperature of } \\
\text { coldest month }\end{array}$ & $\begin{array}{l}\text { Mean 30-year (1981-2010) monthly } \\
\text { temperature of coldest month }\left({ }^{\circ} \mathrm{C}\right) \text {. }\end{array}$ & \\
\hline & $\begin{array}{l}\text { Mean temperature of } \\
\text { warmest month }\end{array}$ & $\begin{array}{l}\text { Mean 30-year (1981-2010) monthly } \\
\text { temperature of warmest month }\left({ }^{\circ} \mathrm{C}\right) \text {. }\end{array}$ & \\
\hline & Aridity Index & $\begin{array}{l}\text { A conditional ratio of precipitation and } \\
\text { Thornthwaite potential evapotranspiration } \\
\text { (see [66]) }\end{array}$ & 10 and $20 \mathrm{~km}$ \\
\hline \multirow{7}{*}{ Elevation [63] } & Minimum & Minimum value & \multirow{7}{*}{$90 \mathrm{~m}$} \\
\hline & Mean & Mean value & \\
\hline & Maximum & Maximum value & \\
\hline & Median & Median value & \\
\hline & Range & $\begin{array}{l}\text { Range between minimum and } \\
\text { maximum values }\end{array}$ & \\
\hline & Standard deviation & Amount of deviance among elevation & \\
\hline & Coefficient of variation & The CV of elevation & \\
\hline Solar [64] & $\begin{array}{l}\text { Day length coefficient } \\
\text { of variation }\end{array}$ & $\begin{array}{l}\text { The CV of } 12 \text { monthly day lengths derived } \\
\text { from the latitude of grid cells. }\end{array}$ & 10 and $20 \mathrm{~km}$ \\
\hline \multirow{8}{*}{ Soil [52] } & $\begin{array}{l}\text { Available water } \\
\text { capacity }(\mathrm{cm})\end{array}$ & $\begin{array}{l}\text { The quantity of water that the soil is capable of } \\
\text { storing for use by plants }\end{array}$ & \multirow{8}{*}{$30 \mathrm{~m}$} \\
\hline & Available water supply (cm) & $\begin{array}{l}\text { The total volume of water that should be } \\
\text { available to plants when the soil, inclusive of } \\
\text { rock fragments, is at field capacity }\end{array}$ & \\
\hline & Bulk density $\left(\mathrm{g} / \mathrm{cm}^{3}\right)$ & $\begin{array}{l}\text { The ovendry weight of the soil material }<2 \mathrm{~mm} \\
\text { in size per unit volume of soil at water tension } \\
\text { of } 1 / 3 \mathrm{bar}\end{array}$ & \\
\hline & Calcium carbonate & $\begin{array}{l}\text { The percent of carbonates, by weight, in the } \\
\text { fraction of the soil }<2 \mathrm{~mm} \text { in size }\end{array}$ & \\
\hline & Cation-exchange capacity & $\begin{array}{l}\text { The total amount of extractable cations that can } \\
\text { be held by the soil, expressed in terms of } \\
\text { milliequivalents per } 100 \text { grams of soil at } \\
\text { neutrality (pH 7.0) or at some other stated } \mathrm{pH}\end{array}$ & \\
\hline & Depth to water table $(\mathrm{cm})$ & Depth to a saturated zone in the soil & \\
\hline & Permeability (cm/h) & $\begin{array}{c}\text { Saturated hydraulic conductivity or the ease } \\
\text { with which pores in a saturated soil } \\
\text { transmit water }\end{array}$ & \\
\hline & Erosion $\mathrm{K}$ factor & $\begin{array}{l}\text { The susceptibility of a soil to sheet and rill } \\
\text { erosion by water estimated by the percentage } \\
\text { of silt, sand, and organic matter and on soil } \\
\text { structure and saturated hydraulic conductivity }\end{array}$ & \\
\hline
\end{tabular}


Table 2. Cont.

\begin{tabular}{|c|c|c|c|}
\hline Category & Variable & Description & Native Resolution \\
\hline & $\begin{array}{l}\text { Erosion T factor } \\
\text { (tons/acre/year) }\end{array}$ & $\begin{array}{l}\text { An estimate of the maximum average annual } \\
\text { rate of soil erosion by wind and/or water that } \\
\text { can occur without affecting crop productivity } \\
\text { over a sustained period }\end{array}$ & \\
\hline & Percent clay & $\begin{array}{l}\text { Mineral soil particles that are }<0.002 \mathrm{~mm} \\
\text { in diameter }\end{array}$ & \\
\hline & Percent sand & $\begin{array}{l}\text { Mineral soil particles that are } 0.05 \mathrm{~mm} \text { to } 2 \mathrm{~mm} \\
\text { in diameter }\end{array}$ & \\
\hline & Percent silt & $\begin{array}{l}\text { Mineral soil particles that are } 0.002 \text { to } 0.05 \mathrm{~mm} \\
\text { in diameter }\end{array}$ & \\
\hline & $\begin{array}{l}\text { Organic matter content (\% } \\
\text { by weight) }\end{array}$ & $\begin{array}{l}\text { Plant and animal residue in soil material } \\
<2 \mathrm{~mm} \text { in diameter at various stages } \\
\text { of decomposition }\end{array}$ & \\
\hline & $\mathrm{pH}$ & A measure of acidity or alkalinity & \\
\hline & Percent passing sieve No. 10 & $\begin{array}{l}\text { Soil fraction passing a number } 10 \text { sieve } \\
(2.00 \mathrm{~mm} \text { square opening })\end{array}$ & \\
\hline & $\begin{array}{l}\text { Percent passing sieve } \\
\text { No. } 200\end{array}$ & $\begin{array}{l}\text { Soil fraction passing a number } 200 \text { sieve } \\
(0.074 \mathrm{~mm} \text { square opening })\end{array}$ & \\
\hline & Soil productivity [65] & $\begin{array}{l}\text { Productivity Index derived from family-level } \\
\text { Soil Taxonomy information }\end{array}$ & \\
\hline & Soil taxonomic order & The percentage of taxonomic order & \\
\hline & Soil texture & $\begin{array}{l}\text { The percentage of clayey, loamy, sandy, or } \\
\text { other texture class defined by USDA } \\
\text { standard terms }\end{array}$ & \\
\hline
\end{tabular}

${ }^{1}$ PRISM Climate Group. 2014. Oregon State University, http:/ / prism.oregonstate.edu.

\subsection{Modeling}

Individual tree species IV were modeled using the randomForest library [67] in R version 3.1.1 [68] (hereafter RF), in which 1001 regression trees were trained with eight randomly selected environmental variables evaluated at each node, and grown to include a minimum of 10 observations. To train the models, only grid cells within the hybrid lattice $(10 \times 10$ or $20 \times 20 \mathrm{~km})$ were used that had (1) two or more FIA plots (to ensure representation within each cell), (2) $\geq 5 \%$ forest cover defined by the 2006 NLCD [69] (classes 41, 42, 43, and 90, to exclude very highly agricultural regions), and (3) a mean $\mathrm{IV} \leq 1.5$ times the inter-quartile range of IVs across all cells (to exclude outliers because they were unlikely to represent the full 100 or $400 \mathrm{~km}^{2}$ ). Each of the 1001 regression trees built by RF provides information about the predicted IV, and the default is to report the mean prediction. However, the random resampling of only eight of 45 variables at each node can result in spurious outcomes due to, for example, omission of an entire class of variables (e.g., climate); while these spurious trees rarely influence overall prediction [70], outliers can influence prediction distributions at a given cell [71]. Therefore, we compared the mean predicted value to the median for each cell; if the median $=0$ and among all 1001 predicted values the coefficient of variation $\geq 2.75$, then 0 was used as the predicted IV rather than the mean; which was $0<$ IVmean $<8$ among all species. This "mean-median" combination is a modification to the approach suggested by Roy and Larocque [71] which limits the influence on outlier predictions, minimizing the area of modeled low suitability, due to a few outliers within the 1001 regression trees for each species.

Once the RF model was trained, predictions of IV were made to all 29,357 cells irrespective of cell size within the hybrid lattice, whether or not at least 2 FIA plots were present, or whether percent forest cover was less or more than five percent. 


\subsection{Model Reliability}

We created a model reliability (ModRel) score from a series of five metrics obtained from the performance statistics of each of 125 species. These included (1) a pseudo $\mathrm{R}^{2}$ obtained from the RF model (RF R ${ }^{2}$ ); (2) a Fuzzy Kappa (FK) metric which compares outputs of the imputed RF-predicted map to the FIA-derived map [72]; (3) the deviance of the CV (CVdev) among 30 regression trees via bagging [41]; and (4) the stability of the top five variables (Top5) from 30 regression trees, and (5) a true skill statistic (TSS) of the imputed RF. The first four were used previously, described in Iverson et al. [42]. The five variables were normalized to a $0-1$ scale and weighted as follows to arrive at a final ModRel score: $0.33 \times \mathrm{RF} \mathrm{R}^{2}+0.33 \times \mathrm{FK}+0.11 \times \mathrm{CVdev}+0.11 \times \mathrm{Top} 5+0.11 \times \mathrm{TSS}$ which gives more weighting to RF $\mathrm{R}^{2}$ and $\mathrm{FK}$, a primary performance metric and a comparison of predicted to observed values, respectively. Then, ModRel scores were assigned to one of four classes: High (ModRel $\geq 0.7)$, medium (0.7 $>$ ModRel $>0.54)$, low $(0.55>$ ModRel $\geq 0.14)$, and unreliable and excluded from further modeling (ModRel $<0.14$ ).

\subsection{Variable Importance}

Each of the 45 predictor variables was scored for all species cumulatively according to a variable importance index, which was the average of three normalized (0-100) scores. First, the variable importance, as calculated within the RF function (percent increase in MSE based original and permuted predictors of the out-of-bag data-see the help for "importance" in randomForest library in R), for each of 125 species was summed. Second, the sum of the reciprocal of ranked predictor importance across all species was calculated; the reciprocal produced higher scores for top ranked variables. Third, the frequency, or count, of the number of times a predictor ranks in the top 10 across all species was tabulated. These metrics allowed comparison among the 45 variables for their value in creating the tree species models. Importantly, these metrics are based on all species across the entire eastern U.S. so that species that have specific requirements will not garner much support with these indicator metrics.

\subsection{Area-Weighted Importance Values}

To incorporate both the area and the relative abundance of each species, we calculated area-weighted importance values for each species. We use area-weighted importance values as a surrogate for the strength of suitable habitat across a species' distribution. The higher the IV score, the higher the tendency for that species to occupy that cell, and the higher the possible basal area of that species within the cell. This measure of suitable habitat is not a probability of occurrence (though likely similar for many species) but rather an indication of the potential of the cell to host the species. Any value above 0 can be considered suitable habitat, though the strength of that habitat varies according to the area-weighted IV score. These values thus provide an estimate of each species' importance based on the IV modeled for each cell (or partial cell), multiplied by the area the cell represents. Because of the variation of grid sizes $\left(100 \mathrm{~km}^{2}\right.$ or $\left.400 \mathrm{~km}^{2}\right)$, due to the hybrid grid structure, and the partial cells especially along coasts, the area-weighted values are truer to their actual and projected future suitable habitat. The ratio of future to present modeled condition represents the potential change of suitable habitat in the future, where values $>1$ indicate an increase in area-weighted importance and values $<1$ indicate a decrease.

\subsection{Changes in Mean Center of Spatial Data}

Within ArcGIS 10.3 (ESRI, Redlands, CA, USA), the Mean Center and Directional Distribution functions were used to calculate the current and future 'center of gravity' and directional ellipse within 1 standard deviation, respectively, of species ranges generated by our models. No weighting was applied to the IV, but only cells modeled to have an IV $>0$ were considered in the calculation of the mean centers and directional ellipses. The coordinates of the mean center were used to calculate distance 
and direction of potential movement of the suitable habitat for each species and were visualized using polar graphs to evaluate potential changes among all species for each scenario of climate change.

\subsection{Analysis of Dominants, Gainers, and Losers}

The area-weighted IV allowed comparison of species prominence and potential change according to the climate scenarios, by spatial domain. These provide valuable supplements to FIA data and state reports (www.fia.fs.fed.us) on the current situation for tree species, as the IVs are based on both density (number of stems) and dominance (basal area) simultaneously. We provide this information for each of 37 states and the District of Columbia, and for five regions within the eastern US. Notably, for the six states split by the 100th meridian (our boundary of the eastern U.S.), some forest patches will be missed but the area in those states west of the 100th meridian is dominated by nonforest or western species (not modeled), with the exception of the Black Hills of South Dakota. We ranked each species according to the modeled current IV and selected the top three for each spatial unit and then calculated the potential changes in area-weighted IV, as ratios of future to current IVs, among the various scenarios of climate change.

\subsection{Species-Level Maps}

Maps representing species (abundance and suitable habitat under various scenarios) were generated for each species. Specifically, the maps show outputs of the (1) FIA estimate of current abundance, (2) modeled current distribution, and the future distributions according to the (3) CCSM45, (4) CCSM85, (5) GFDL45, (6) GFDL85, (7) Had45, (8) Had85, (9) mean of all three RCP4.5, and (10) mean of all three RCP8.5 scenarios.

\subsection{Comparison to Earlier DISTRIB Models}

We have been modeling tree species suitable habitat within the eastern U.S. since $1998[17,39,40,42,43]$, and there have been changes in many dimensions throughout this period. First, we modeled 80 species at the county level of resolution, then 134 species at $20 \times 20 \mathrm{~km}$ resolution, and most recently 125 species at a hybrid of $10 \times 10$ and $20 \times 20 \mathrm{~km}$ resolution, depending on the density of FIA plots ( forest cover). Throughout the period, there has also been a remarkable improvement in environmental data, especially climate and soils data. And, the modeling improvement from regression tree analysis to random forests [41] was particularly dramatic in enhancing model performance. As expected when using multiple models, updated data sets, or variations in modelling technique, model outcomes will differ between iterations; this is true in this case too.

\subsection{Scope and Limitations}

The models depicted here represent changes in potentially suitable habitat according to scenarios of climate change; they do not depict projections of actual future distributions by 2100. Earlier work has shown that natural migration proceeds at a much slower pace than change in habitat, especially for long-lived trees $[17,73-75]$. Therefore, our projections of an increase in the range are likely to overestimate the actual distributions by century's end, unless humans get seriously involved in moving species.

Though Random Forest has been shown to be a robust modeling tool, highly resistant to overfitting, we sometimes are making predictions into novel parameter space through extrapolation; nonetheless, the resistance to overfitting of Random Forest predictions gives us confidence that the extrapolations are suitably constrained and are not exaggerated projections [41]. Obviously, not all 125 species models are created equal, and we calculate several metrics to assess model reliability for each species [42].

When we model potential changes in suitable habitat, one would normally expect the greatest impacts to be experienced by young plants at the point of regeneration, when seedlings or saplings are more susceptible to the increased extreme weather events and other ramifications of the changing 
climate. However, mature forests are certainly also susceptible, either directly via droughts, especially 'hot' droughts [76], or indirectly via pests and pathogens [77]. Because the models are based on FIA inventories of trees $>2.5 \mathrm{~cm}$ dbh, the regeneration component is not well represented in the model formulations. We are modeling the potential niche space that may be available to species under future climates, which may not be the realized niche because disturbances and extreme events will be operating within the suitable habitats. Though the FIA data, in effect, integrates past disturbances by documenting those species that have survived past events, we cannot anticipate future disturbances (like an exotic pest invasion) that will influence actual future distribution and abundance. Further, we cannot assume that all species are in equilibrium with their current climate or other environmental variables.

\section{Results and Discussion}

\subsection{Model Reliability and Variable Importance}

Of the 125 species in this assessment, we scored 29 species with high model reliability, 47 with medium, and 49 with lower model reliability. These model reliability classes are presented for each species in Table A1. Admittedly, the cut off values presented in the methods section are arbitrary and adjusting the cut offs would change the proportion of each model reliability class. We chose to stay conservative in assigning the cut offs, leading to a loading of species at the lower end of reliability.

When we scored each of the 45 predictor variables according to a variable importance index, we found the climate variables dominated in importance. In fact, seven of the top nine variables were the climate variables. Of course, several of these variables are correlated with each other across the entire eastern U.S. but will be important locally for particular species. The first and second ranked variables were summer (30-year mean of the warmest month) and winter (30-year mean of the coldest month) temperatures; these indicate some species are limited by cold, some are linked to warm temperatures, and some may be driven by both together. Because these metrics are based on all species across the entire eastern U.S., the wide ranging, generalist species will tend to be correlated with wide ranging temperature or precipitation patterns as well. The day length coefficient of variation among months (based on latitude) was the most influential non-climate variable, followed by soil variables $\mathrm{pH}$, texture (soil fraction passing a sieve with a $2 \mathrm{~mm}$ square opening), soil productivity (based on soil taxonomic family), and permeability (saturated hydraulic conductivity). The lower ranked variables, though not rated high for all species together, will rank high for individual species in particular habitats, etc. Though space prevents discussion of individual species and their variables of importance, these will be presented in upcoming updates to our Climate Change Tree Atlas (www.fs.fed.us/nrs/atlas).

\subsection{Potential Changes in Species Area-weighted Importance Values}

For the 125 species with acceptable models, Table 3 provides an indication of the quantity of species that may lose (Future: Current ratios $<0.9$ ) or gain (ratios $>1.1$ ) suitable habitat by 2100 , as well as those projected to remain somewhat stable $(0.9<$ ratios $<1.1)$. Averaged across all scenarios, 88 species showed at least a $10 \%$ increase in area-weighted IV, and 26 species showed at least a $10 \%$ decrease, with 12 species having little or no change (Table 3). For those 88 species inclined to have increasing habitat, the RCP8.5 scenario showed more species at least doubling habitat (55 species) than under the RCP4.5 scenario (42 species) of lower emissions. Notably, there was not much difference between RCPs for those species losing habitat (Table 3). Species included among those projected to lose substantial habitat are: Acer nigrum Michx. f. (black maple), A. spicatum Lam. (mountain maple), Picea mariana (black spruce), Populus balsamifera L. (balsam poplar), Prunus pensylvanica L.f. (pin cherry), and Sorbus americana Marshall (American mountain-ash) (Table A1). Among those species showing substantial increases in suitable habitat are: Carpinus caroliniana Walter (American hornbeam), Celtis laevigata Willdenow (sugarberry), Magnolia grandiflora L. (southern magnolia), Ostrya virginiana (Mill.) K.Koch (eastern hophornbeam), Pinus echinata Mill. (shortleaf pine), P. palustris 
Mill. (longleaf pine), Quercus falcata Michx. (southern red oak), Quercus marilandica Muenchh. (blackjack oak), Quercus michauxii Nutt. (swamp chestnut oak), Q. nigra (water oak), Q. phellos (willow oak), Quercus phellos L. (post oak), Quercus phellos L. (live oak), Taxodium distichum (L.) Rich. (bald cypress), and Ulmus alata Michx. (winged elm) (Table A1).

Table 3. Potential species changes in area-weighted importance value for habitat suitability for 125 species in the eastern United States. Allowing for a $10 \%$ buffer around the future:current ratio of 1.0 (i.e., no change), values below 0.9 indicates a loss, while values above 1.1 indicate a gain in suitable habitat. Scenarios refer to model (CCSM, GFDL, Had, and mean of all three GCM models) and emission level (RCP 4.5 and 8.5).

\begin{tabular}{ccccccc}
\hline & \multicolumn{7}{c}{ Future: Current Ratios of Importance Values } \\
\hline Scenario & $<\mathbf{0 . 5}$ & $\mathbf{0 . 5 - 0 . 9}$ & $\mathbf{0 . 9 - 1 . 1}$ & $\mathbf{1 . 1 - 2}$ & $\mathbf{> 2}$ & Total \\
\hline CCSM45 & 6 & 18 & 14 & 64 & 23 & $\mathbf{1 2 5}$ \\
CCSM85 & 7 & 16 & 13 & 40 & 49 & $\mathbf{1 2 5}$ \\
GFDL45 & 8 & 15 & 13 & 39 & 50 & $\mathbf{1 2 5}$ \\
GFDL85 & 6 & 18 & 10 & 31 & 60 & $\mathbf{1 2 5}$ \\
HAD45 & 7 & 20 & 12 & 38 & 48 & $\mathbf{1 2 5}$ \\
HAD85 & 8 & 24 & 8 & 35 & 50 & $\mathbf{1 2 5}$ \\
GCM45 & 8 & 17 & 11 & 47 & 42 & $\mathbf{1 2 5}$ \\
GCM85 & 7 & 19 & 9 & 35 & 55 & $\mathbf{1 2 5}$ \\
\hline
\end{tabular}

The data do show that for many of the species gaining in excess of $10 \%$ in habitat, they are often from less reliably modeled species than those species losing habitat. For example, only 12 of 88 species $(14 \%)$ which show at least $10 \%$ increase in habitat had highly reliable models, but 12 of 26 species (46\%) showing a decrease of at least $10 \%$ had highly reliable models (Table A1). For those more common species (arbitrarily selected as those with the sum of IV >15,000), those ratios are 11 of $34(32 \%)$ for gainers compared to 8 of $8(100 \%)$ for the losers. The large gainers fall into three categories: First, the species is currently common in a region that is now quite warm and fairly dry, that being the southwestern portion of the eastern U.S. (e.g., Texas, Oklahoma, southern Missouri). These species, like Quercus stellata (post oak), Quercus marilandica Muenchh. (blackjack oak), Carya texana Buckley (1861) (black hickory), ashe juniper (Juniperus ashei J. Buchholz) and Juniperus virginiana L. (eastern red cedar), are primarily temperature driven, and expand greatly in suitable habitat when provided much warmer temperatures as projected under climate change. Second, the species is currently quite rare or sparse according to current FIA plot data, and the models project the species to 'fill in' some additional territory with suitable habitat. Species in this category include Diospyros virginiana L. (common persimmon), Ilex opaca Aiton (American holly), and Ostrya virginiana (Mill.) K.Koch (eastern hophornbeam). Third, the species is an important southern species now but is expected to substantially expand its suitable habitat northward by end of the century. These species include Quercus falcata (southern red oak), Quercus nigra L. (water oak), Pinus echinata (shortleaf pine), and P. palustris (longleaf pine) (Table A1).

\subsection{Changes in Mean Center of Spatial Data}

The potential changes in mean centers of suitable habitat under various scenarios of climate change indicate that roughly 3-4 times as many species show habitat movement in a northerly direction as compared to a southerly direction (Table 4, Figure 3). As many as 81 species (RCP8.5 mean) could have mean center movement at least $100 \mathrm{~km}$ northward. The data also clearly show that those northward-moving species will likely have their mean habitat centers move greater distances under the hotter (RCP8.5) scenarios as compared to the RCP4.5 scenarios. Some of the species modeled to move habitats long distances northward include Carya texana (black hickory), Quercus virginiana (live oak), and Ulmus crassifolia (winged elm) (Figure 3). The scenario with the least change in temperature, CCSM45, also shows less northward movement of mean centers, but this scenario still has 54 species 
moving habitats at least $100 \mathrm{~km}$ by the end of the century. Some of the species moving habitats southward include Acer pensylvanicum L. (striped maple), Prunus pensylvanica (pin cherry), and Sorbus americana (American mountain ash) (Figure 3); these species models, however, had lower model reliability and are complicated by the geographic influence of the spine of the Appalachian Mountains. Example maps showing the mean centers and their ellipses around current and potential future habitat distributions for two southern species, Liquidambar styraciflua L. and Pinus echinata, are shown in Figure 4. Fei et al. [78], in an analysis of FIA data across three decades for 86 species/groups in the eastern U.S., found that $62 \%$ of species show evidence for a northward shift and that $73 \%$ of species show evidence for a westward shift. This westward trend was associated with changes in moisture availability (more moisture now westward) and successional trends (afforestation farther west), though the much sparser FIA data westward into the highly agricultural Midwestern Corn Belt can also contribute to the differences in results with ours. Of the species we have in common $(n=78)$ with the Fei et al. study, our results from the GCM85 scenario show much more potential for northward $(87 \% \mathrm{~N}, 13 \% \mathrm{~S})$ over westward $(31 \% \mathrm{~W}, 69 \% \mathrm{E})$ migration of climatically suitable habitat. In future, the GCMs do show a lot more warming northward as compared to the previous 30 years $[78,79]$, and when coupled with a probable constraint of the increased moisture westward [79], these two studies are not incongruent.
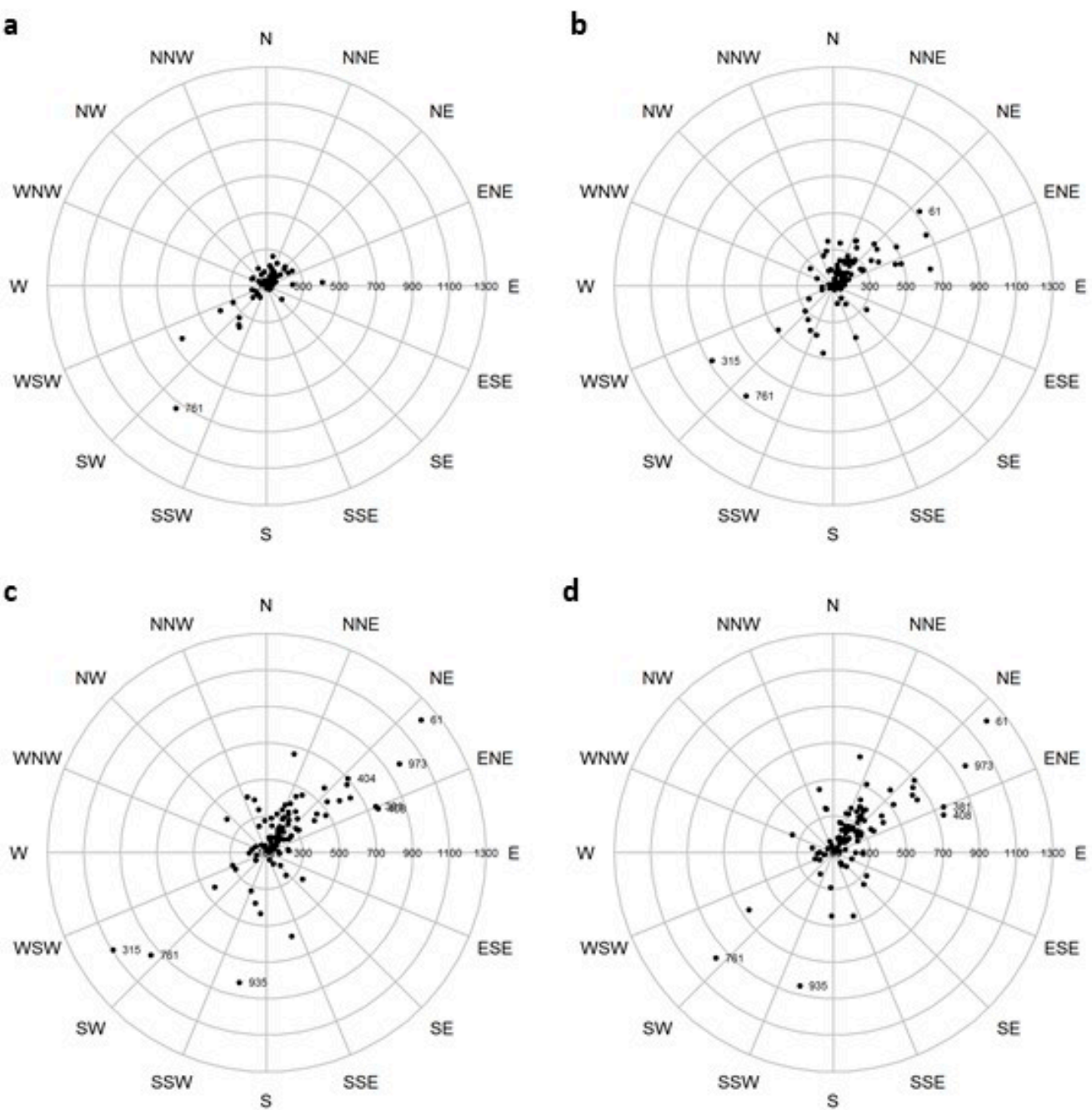

Figure 3. Potential changes in distance and direction of mean centers of suitable habitat for each of 125 species, according to (a) CCSM45, (b) GCM45, (c) GCM85), and (d) GFDL85. These are the 'bookends' of severity (CCSM45 and Had85) and the means (GCM45 and GCM85) of all three models. 
Table 4. Number of species by distance and generalized northward and southward direction of mean centers of suitable habitat for the 125 species in the eastern United States. Only the 'bookends' of severity (CCSM45 and Had85) and the means (GCM45 and GCM85) of all three models are presented.

\begin{tabular}{ccccccccc}
\hline \multirow{2}{*}{ Scenario } & \multicolumn{7}{c}{ Kilometers } \\
\cline { 2 - 9 } & $\mathbf{1 0}$ & $\mathbf{1 0 - 5 0}$ & $\mathbf{5 1 - 1 0 0}$ & $\mathbf{1 0 1 - 2 0 0}$ & $\mathbf{2 0 1 - 3 0 0}$ & $\mathbf{3 0 1 - 4 0 0}$ & $>\mathbf{4 0 0}$ & Total \\
\hline Northward & & & & & & & & \\
CCSM45 & 1 & 16 & 22 & 43 & 10 & 0 & 1 & 93 \\
GCM45 & 1 & 12 & 19 & 33 & 19 & 7 & 8 & 99 \\
GCM85 & 0 & 9 & 11 & 25 & 23 & 16 & 17 & 101 \\
Had85 & 0 & 8 & 17 & 22 & 19 & 18 & 16 & 100 \\
\hline Southward & & & & & & & & \\
CCSM45 & 0 & 7 & 7 & 10 & 1 & 5 & 2 & 32 \\
GCM45 & 0 & 0 & 5 & 9 & 2 & 5 & 5 & 26 \\
GCM85 & 0 & 3 & 2 & 6 & 4 & 3 & 6 & 24 \\
Had85 & 0 & 2 & 4 & 5 & 7 & 2 & 5 & 25 \\
\hline
\end{tabular}

A

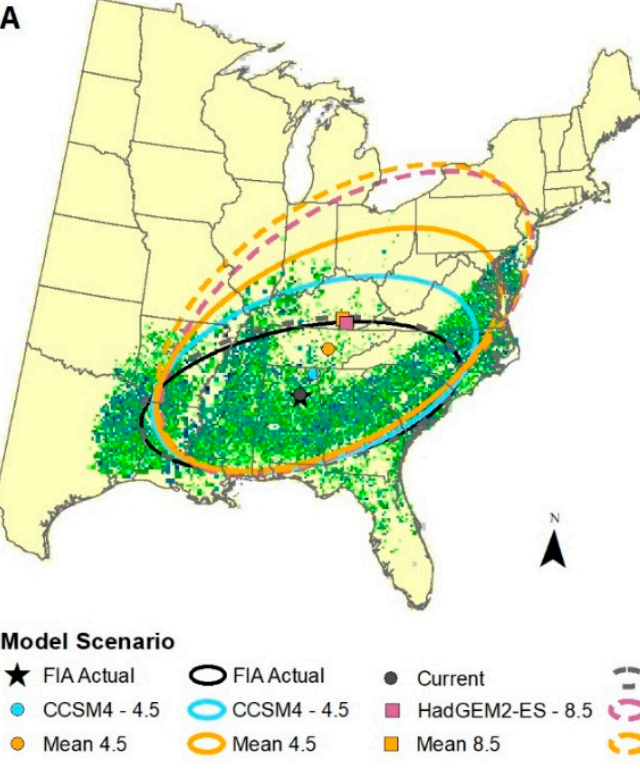

B

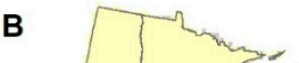

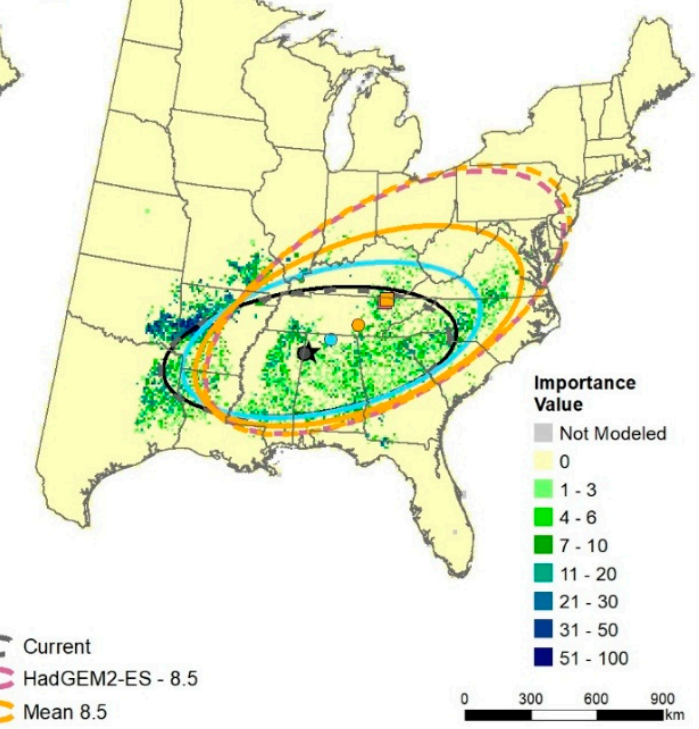

Figure 4. Ellipses of 1 standard deviation and mean centers for the current distribution and suitable habitat according to CCSM45, GCM45, GCM85, and Had85 under RCP 4.5 (circles) and 8.5 (squares) for (A) Liquidambar styraciflua and (B) Pinus echinata. Only the 'bookends' of severity (CCSM45 and Had85) and the means (GCM45 and GCM85) of all three models are presented. FIA Actual refers to the known FIA plot locations of the species, while Current refers to the modeled current distribution of the species.

Numbers represent the FIA species codes for a few species with potential long distance movements (shown in km): 61 = Juniperus ashei J. Buchholz, $315=$ Acer pensylvanicum L., $404=$ Carya illinoensis (Wangenh.) K.Koch, 408 = Carya texana Buckley, 761 = Prunus pensylvanica L.f., 935 = Sorbus americana, 973 = Ulmus crassifolia.

\subsection{Analysis of Dominants, Gainers, and Losers by State and Region}

In this analysis we identified, for the entire East, five regions, and 37 states plus the District of Columbia, the dominant three species now and what their overall changes are projected for suitable habitat, with 1 meaning no change, $<1$ meaning a loss in habitat, and $>1$ meaning a gain in habitat (Table 5). Over the entire eastern U.S., the top three species currently are loblolly pine (Pinus taeda), red maple (Acer rubrum), and sweetgum (Liquidambar stryraciflua L.). Of the 36 unique species ranked among the top three positions, those that most frequently scored among the dominant three species 
are red maple (for 21 of 44 states or regions), loblolly pine (15 of 44), sugar maple (Acer saccharum, 11 of 44), and sweetgum (10 of 44) (Table 5). By genus, the three Acer species were found among the top three species 33 times, the five Pinus species 25 times, and the nine Quercus species 23 times.

For the top three species within the 38 state (and District of Columbia) rankings ( $n=114), 50$ $(44 \%)$ are expected to lose $>10 \%$ of their suitable habitat, while $41(36 \%)$ species are projected to gain $>10 \%$ of habitat by 2100 for the RCP 4.5 scenario; comparable numbers under RCP 8.5 are 58 $(51 \%)$ losers and $40(35 \%)$ gainers. So, although more of these dominant species are expected to lose habitat suitability in the changed climate, the fact that they are abundant presently and often very adaptable to a changing climate $[80,81]$ increases the probability that many of these species, even the losers, may still be plentiful in their respective states by 2100 .

Contrary to the data for the entire suite of 125 species, where 88 species were modeled to gain at least $10 \%$ habitat (Table 3), the analysis of only the top three species by state or region shows that a larger number of species are projected to lose habitat as compared to gain habitat (Table 5). Of the 132 iterations of species listed on Table 5 under regions or states, 56 species lost $>10 \%$ habitat and 51 gained $>10 \%$ habitat. Primary losers were Acer rubrum, A. saccharum, Liriodendron tulipifera L., and Populus tremuloides, while primary gainers were Pinus taeda and Liquidambar styraciflua. 
Table 5. Top three species currently in each region and state, along with the future:current ratio of projected suitable habitat under low and high emission scenarios.

\begin{tabular}{|c|c|c|c|c|c|c|c|c|c|}
\hline State/Region & First Species & Low & High & Second Species & Low & High & Third Species & Low & High \\
\hline Eastern U.S. & Pinus taeda & 1.21 & 1.32 & Acer rubrum & 0.99 & 0.92 & Liquidambar styraciflua & 1.48 & 1.73 \\
\hline Northeast & Acer rubrum & 0.91 & 0.76 & Acer saccharum & 0.93 & 0.88 & Pinus strobus & 1.04 & 0.87 \\
\hline North Central & Populus tremuloides & 0.71 & 0.61 & Acer rubrum & 1 & 0.93 & Acer saccharum & 1.03 & 0.98 \\
\hline Great Plains & Ulmus americana & 1.44 & 1.74 & Celtis occidentalis & 1.53 & 1.58 & Juniperus virginiana & 2.64 & 3.07 \\
\hline Southeast & Pinus taeda & 1.07 & 1.09 & Pinus elliottii & 1.31 & 1.42 & Liquidambar styraciflua & 1.34 & 1.43 \\
\hline South Central & Pinus taeda & 1.2 & 1.2 & Liquidambar styraciflua & 1.35 & 1.42 & Quercus stellata & 2.15 & 2.44 \\
\hline Alabama & Pinus taeda & 0.98 & 0.95 & Liquidambar styraciflua & 1.17 & 1.21 & Quercus nigra & 2.04 & 2.29 \\
\hline Arkansas & Pinus taeda & 1.35 & 1.36 & Pinus echinata & 1.55 & 1.56 & Quercus alba & 0.84 & 0.82 \\
\hline Connecticut & Acer rubrum & 0.7 & 0.54 & Betula lenta & 0.65 & 0.54 & Quercus rubra & 0.89 & 0.77 \\
\hline District of Columbia & Liriodendron tulipifera & 0.34 & 0.29 & Fagus grandifolia & 0.44 & 0.44 & Quercus prinus & 0.5 & 0.49 \\
\hline Delaware & Acer rubrum & 0.77 & 0.69 & Pinus taeda & 2.38 & 2.4 & Liquidambar styraciflua & 1 & 1.07 \\
\hline Florida & Pinus elliottii & 0.93 & 0.89 & Pinus taeda & 1.31 & 1.46 & Quercus laurifolia & 1.17 & 1.15 \\
\hline Georgia & Pinus taeda & 0.97 & 0.95 & Pinus elliottii & 1.19 & 1.27 & Liquidambar styraciflua & 1.23 & 1.29 \\
\hline Iowa & Ulmus americana & 1.23 & 1.27 & Juglans nigra & 1.39 & 1.33 & Celtis occidentalis & 2.24 & 2.02 \\
\hline Illinois & Ulmus americana & 1.29 & 1.47 & Quercus alba & 0.92 & 0.76 & Prunus serotina & 0.77 & 0.66 \\
\hline Indiana & Acer saccharum & 0.73 & 0.64 & Prunus serotina & 0.74 & 0.6 & Fraxinus americana & 0.99 & 0.94 \\
\hline Kansas & Ulmus americana & 1.15 & 1.23 & Celtis occidentalis & 1.07 & 1.06 & Maclura pomifera & 1.21 & 1.22 \\
\hline Kentucky & Liriodendron tulipifera & 0.44 & 0.35 & Acer saccharum & 0.66 & 0.6 & Quercus alba & 1.01 & 0.95 \\
\hline Maryland & Acer rubrum & 0.8 & 0.72 & Pinus taeda & 2.32 & 2.67 & Liriodendron tulipifera & 0.65 & 0.47 \\
\hline Maine & Abies balsamea & 0.53 & 0.5 & Acer rubrum & 1.35 & 1.24 & Picea rubens & 0.64 & 0.57 \\
\hline Michigan & Acer rubrum & 0.98 & 0.87 & Acer saccharum & 0.82 & 0.74 & Populus tremuloides & 0.89 & 0.8 \\
\hline Minnesota & Populus tremuloides & 0.66 & 0.56 & Picea mariana & 0.4 & 0.4 & Larix laricina & 1.21 & 1.17 \\
\hline Missouri & Quercus alba & 0.57 & 0.52 & Quercus velutina & 0.95 & 0.86 & Quercus stellata & 1.74 & 1.94 \\
\hline Mississippi & Pinus taeda & 1.09 & 1.01 & Liquidambar styraciflua & 1.19 & 1.2 & Quercus nigra & 2.05 & 2.27 \\
\hline North Carolina & Pinus taeda & 1.21 & 1.24 & Acer rubrum & 0.79 & 0.77 & Liquidambar styraciflua & 1.28 & 1.39 \\
\hline North Dakota & Quercus macrocarpa & 1.75 & 2.58 & Populus tremuloides & 0.42 & 0.33 & Acer negundo & 1.92 & 1.63 \\
\hline Nebraska & Juniperus virginiana & 1.92 & 2.33 & Quercus macrocarpa & 1.59 & 1.57 & Ulmus americana & 2.1 & 2.51 \\
\hline New Hampshire & Acer rubrum & 1.06 & 0.91 & Pinus strobus & 0.79 & 0.65 & Tsuga canadensis & 0.77 & 0.66 \\
\hline New Jersey & Pinus rigida & 0.39 & 0.39 & Acer rubrum & 1.05 & 0.92 & Quercus alba & 1 & 0.83 \\
\hline New York & Acer rubrum & 0.98 & 0.77 & Acer saccharum & 0.78 & 0.71 & Fagus grandifolia & 0.73 & 0.67 \\
\hline Ohio & Acer rubrum & 0.47 & 0.4 & Acer saccharum & 0.89 & 0.79 & Prunus serotina & 0.67 & 0.55 \\
\hline Oklahoma & Quercus stellata & 1.09 & 1.08 & Juniperus virginiana & 1.24 & 1.34 & Pinus echinata & 1.36 & 1.4 \\
\hline Pennsylvania & Acer rubrum & 0.64 & 0.47 & Prunus serotina & 0.77 & 0.63 & Acer saccharum & 0.91 & 0.86 \\
\hline
\end{tabular}


Table 5. Cont.

\begin{tabular}{|c|c|c|c|c|c|c|c|c|c|}
\hline State/Region & First Species & Low & High & Second Species & Low & High & Third Species & Low & High \\
\hline Rhode Island & Acer rubrum & 0.62 & 0.52 & Pinus strobus & 0.55 & 0.42 & Quercus rubra & 0.72 & 0.62 \\
\hline South Carolina & Pinus taeda & 0.86 & 0.81 & Liquidambar styraciflua & 1.08 & 1.09 & Quercus nigra & 1.8 & 2.03 \\
\hline South Dakota & Quercus macrocarpa & 5.57 & 5.65 & Juniperus virginiana & 5.87 & 6.93 & Fraxinus pennsylvanica & 3.75 & 4.15 \\
\hline Texas & Pinus taeda & 0.97 & 0.9 & Juniperus ashei & 1.11 & 1.1 & Quercus virginiana & 1.49 & 1.55 \\
\hline Virginia & Pinus taeda & 1.45 & 1.66 & Liriodendron tulipifera & 0.5 & 0.33 & Acer rubrum & 0.82 & 0.76 \\
\hline Vermont & Acer saccharum & 0.61 & 0.57 & Acer rubrum & 1.39 & 1.25 & Fagus grandifolia & 0.76 & 0.72 \\
\hline Wisconsin & Populus tremuloides & 0.7 & 0.62 & Acer rubrum & 0.97 & 0.8 & Acer saccharum & 0.94 & 0.92 \\
\hline
\end{tabular}




\subsection{Species-Level Maps}

Though putting 10 maps on a page masks fine-scale visualization, it does provide a way to assess the current distribution according to the relatively sparse FIA plots, the modeled current distribution, and the potential future distributions according to each of the model/RCP scenarios, as well as the mean RCP 4.5 and 8.5. For example, Liriodendron tulipifera (yellow poplar), a species important for wood products throughout its range (Figure 5) shows a general northward expansion of suitable habitat under warming, with more expansion under RCP8.5 vs. RCP4. The least expansion is with the relatively cool CCSM4 model as compared to the more equivalent Hadley and GFDL models. However, with the driest Hadley model (either RCP4.5 or RCP8.5), habitat for yellow poplar noticeably contracts in the southern third of its current distribution (Figure 5). These maps are available in Figures A1-A3 for three other species, Pinus echinata (shortleaf pine) P. teada (loblolly pine), and Liquidambar styraciflua (sweetgum); all species will eventually be on our atlas website www.fs.fed.us/nrs/atlas.

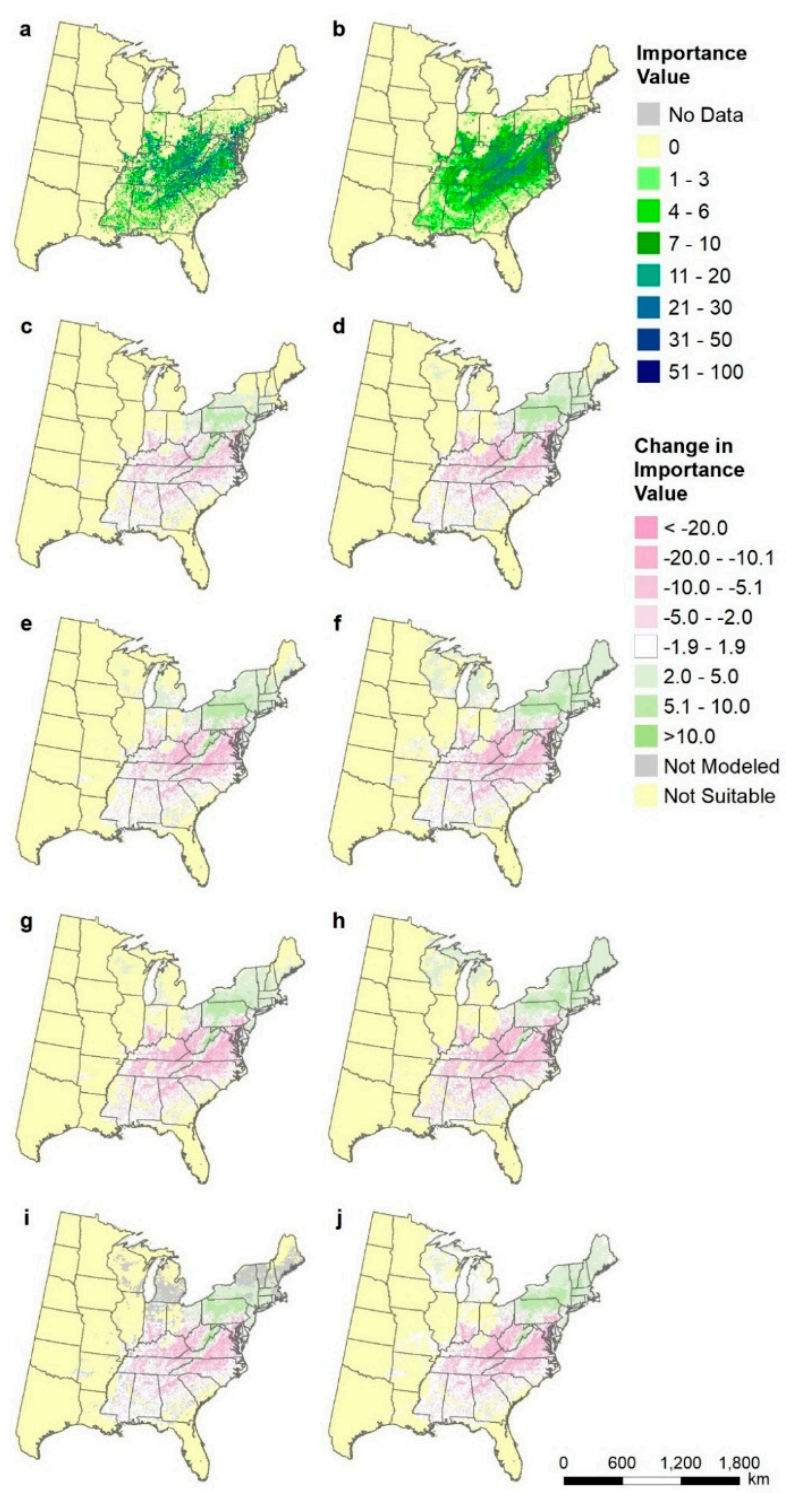

Figure 5. Liriodendron tulipifera (yellow poplar) distributions, shown as differences from current modeled distribution (map b): (a) FIA estimate of current distribution of abundance, (b) modeled current distribution, (c) CCSM45, (d) CCSM85, (e) GFDL45, (f) GFDL85, (g) Had45, (h) Had85, (i) mean of all three RCP4.5, and (j) mean of all three RCP8.5. 


\subsection{Comparison to Earlier DISTRIB Models}

As expected, there are differences between DISTRIB-II outputs described here from those presented in our earlier work [15]. In our current effort, differences mainly arise from using a hybrid lattice approach, and also from: (1) Newer FIA records, (2) recent 30-year climate normals, (3) a newer set of predictor variables, (4) removal of outlier training data, and (5) modifying predicted IVs with the mean-median combination. The recent FIA records provide information about disturbances and changes in species demographics, while the 30-year climate normals attempt to match conditions experienced by the trees inventoried by FIA. The newer set of environmental predictors incorporates finer scale information (e.g., gSSURGO soils), as well as additional variables not previously used. The removal of outliers from training datasets aims to limit the influence of unrepresentative cells that might result from plantations or severe disturbance events, while the modification of predicted values with the mean-median combination reduced the influence of spurious predictions among the prediction set.

Attributing the differences in results between DISTRIB and DISTRIB-II to any single or combination of the listed factors would be very difficult to quantify and of little practical value to forest managers. Suffice it to say that the newer results are an improvement over the earlier ones. However, as with our earlier results, models with low reliability should be interpreted with caution. As always with modeling studies, 'all models are wrong' [82]; we strive to make them useful by making them available to use in concert with any other information and experience available to the decision makers.

\section{Conclusions}

The forests of the eastern United States are characterized by a diverse assemblage of tree species. Climate change has the potential to shift and influence species patterns, thereby creating novel communities, with the greatest disruption and change clearly linked to the emissions pathways that unfold over the course of this century. By quantifying potential habitat changes across a wide array of species over a broad geographic extent, we can consider several dimensions of potential habitat change that lend to understanding individual species responses, as well as focused regional quantification that lend to informed on-the-ground adaptation planning. The trend of increasing general habitat conditions for a large portion of the species is a function of spreading at the range margin extents with, in many cases, a decline in core habitat suitability. Those species projecting losses, while fewer in number, generally show a contraction in the range of suitable habitat under either RCP, but especially so under RCP 8.5. In many cases, a finer extent of regions or state level evaluations reveals the potential impact of shifting habitats via ranked species importance and summary of winners and losers by states or regions. In these more discrete extents, the gradual fading in or out for species presents useful information for planners. Many of the current top species projected to decline in the region (even though their range-wide ratio may be increasing) epitomize the conditions where macro level pressures of climate change can have local level implications. In the end, these results show the high potential for a reshuffling of where suitable habitats for species will occur across the eastern United States, and it is clear that these will reshape competitive pressures and ultimate final outcomes that are beyond any modeling approach. Therefore, we intend these models to be one piece of a package of information that practitioners use for decisions related to adapting to the changing climate we now face. Working together, adaptations in silviculture and ecological management should improve the potential for eastern U.S. forests to continue to thrive in the coming decades.

Author Contributions: All four authors cooperated on conceptualization, methodology, validation, formal analysis, investigation, data curation, visualization, review and editing, and preparing the proposal for funding. L.R.I. prepared the original draft, and supervised and administered the overall project.

Funding: This research was funded by the USDA Forest Service, Northern Research Station, the Northern Institute of Applied Climate Science, and the USDA Climate Hubs as part of their appropriated funding. 
Acknowledgments: Climate scenarios used were from the NEX-DCP30 dataset, prepared by the Climate Analytics Group and NASA Ames Research Center using the NASA Earth Exchange, and distributed by the NASA Center for Climate Simulation (NCCS). We appreciate reviews by Bryce Adams, Patricia Leopold, and Chris Swanston, along with the editors and reviewers of this Forests issue.

Conflicts of Interest: The authors declare no conflict of interest The funders had no role in the design of the study; in the collection, analyses, or interpretation of data; in the writing of the manuscript, or in the decision to publish the results.

\section{Appendix A}

Table A1. Importance value $\times$ area scores (FIAsumIV) and their future:current ratios showing potential gains (light green 1.1-2.0, dark green $>2.0$-fold increase) or losses (orange 0.5-0.9, red $<0.5$ times decrease) or no change (black 0.9-1.1) under three scenarios of climate change: CCSM4.5, GFDL8.5, Had8.5 and mean of the three models for each RCP (GCM45 and GCM85). Also shown is overall average score (GCMave), and the model reliability for each species.

\begin{tabular}{|c|c|c|c|c|c|c|c|c|}
\hline Scientific Name & $\begin{array}{c}\text { Model } \\
\text { Reliability }\end{array}$ & $\begin{array}{c}\text { FIA } \\
\text { sumIV }\end{array}$ & CCSM45 & GFDL85 & HAD85 & GCM45 & GCM85 & GCMave \\
\hline Abies balsamea (L.) Mill. & High & 35,606 & 0.496 & 0.504 & 0.492 & 0.495 & 0.506 & 0.500 \\
\hline Acer barbatus Michx. & Low & 1729 & 1.758 & 5.877 & 5.654 & 3.026 & 5.277 & 3.631 \\
\hline Acer negundo L. & Low & 25,259 & 1.356 & 2.096 & 1.887 & 1.637 & 1.889 & 1.763 \\
\hline Acer nigrum L. & Low & 678 & 0.409 & 0.292 & 0.282 & 0.364 & 0.299 & 0.340 \\
\hline Acer pensylvanicum L. & Medium & 2549 & 0.752 & 0.565 & 0.547 & 0.672 & 0.580 & 0.653 \\
\hline Acer rubrum L. & High & 165,591 & 1.030 & 0.915 & 0.871 & 0.993 & 0.920 & 0.956 \\
\hline Acer saccharinum L. & Low & 14,872 & 1.804 & 3.044 & 2.445 & 2.309 & 2.630 & 2.203 \\
\hline Acer saccharum Marshall & High & 88,010 & 0.945 & 0.906 & 0.819 & 0.932 & 0.880 & 0.906 \\
\hline Acer spicatum Lam. & Low & 472 & 0.214 & 0.177 & 0.171 & 0.177 & 0.164 & 0.220 \\
\hline Aesculus flava Sol. & Low & 1682 & 0.895 & 0.666 & 0.564 & 0.775 & 0.682 & 0.705 \\
\hline Aesculus glabra Willd. & Low & 999 & 0.720 & 0.588 & 0.572 & 0.640 & 0.584 & 0.603 \\
\hline Amelanchier spp. & Low & 2558 & 0.956 & 1.278 & 1.250 & 1.024 & 1.181 & 1.015 \\
\hline Asimina triloba (L.) Dunal & Low & 738 & 0.488 & 0.519 & 0.518 & 0.495 & 0.497 & 0.481 \\
\hline Betula alleghaniensis Britt. & High & 17,123 & 0.828 & 0.635 & 0.634 & 0.753 & 0.654 & 0.703 \\
\hline Betula lenta $\mathrm{L}$. & High & 13,368 & 1.029 & 0.806 & 0.802 & 0.966 & 0.844 & 0.909 \\
\hline Betula nigra L. & Low & 3988 & 1.632 & 6.922 & 8.275 & 4.053 & 6.875 & 4.749 \\
\hline Betula papyrifera Marshall & High & 21,096 & 0.940 & 0.833 & 0.779 & 0.918 & 0.834 & 0.876 \\
\hline Betula populifolia Marsh. & Low & 1622 & 1.045 & 1.293 & 1.157 & 1.154 & 1.191 & 1.095 \\
\hline Carpinus caroliniana Walter & Low & 9337 & 2.417 & 4.278 & 3.472 & 2.913 & 3.756 & 2.954 \\
\hline Carya alba Sarg. & Medium & 22,233 & 1.831 & 2.998 & 3.185 & 2.267 & 2.920 & 2.593 \\
\hline Carya aquatica (F.Michx.) Nutt. & Medium & 2624 & 1.278 & 1.619 & 1.699 & 1.380 & 1.641 & 1.393 \\
\hline $\begin{array}{c}\text { Carya cordiformis (Wangenh.) } \\
\text { K.Koch }\end{array}$ & Low & 12,853 & 1.468 & 2.757 & 2.284 & 1.859 & 2.315 & 1.882 \\
\hline Carya glabra Miller & Medium & 22,303 & 1.240 & 1.494 & 1.318 & 1.280 & 1.401 & 1.341 \\
\hline $\begin{array}{c}\text { Carya illinoinensis (Wangenh.) } \\
\text { K.Koch }\end{array}$ & Low & 6698 & 2.613 & 13.336 & 15.386 & 5.479 & 12.017 & 7.580 \\
\hline Carya laciniosa (Mill.) K.Koch & Low & 1009 & 1.051 & 1.767 & 1.080 & 1.241 & 1.340 & 1.177 \\
\hline Carya ovate (Mill.) K.Koch & Medium & 19,547 & 1.149 & 1.356 & 1.170 & 1.281 & 1.262 & 1.271 \\
\hline Carya texana Buckley (1861) & High & 9390 & 2.126 & 6.676 & 7.545 & 3.686 & 6.198 & 4.358 \\
\hline Celtis laevigata Willdenow & Medium & 16,556 & 2.469 & 6.786 & 7.940 & 3.893 & 6.580 & 5.236 \\
\hline Celtis occidentalis L. & Medium & 21,798 & 1.516 & 2.420 & 1.974 & 1.861 & 2.076 & 1.968 \\
\hline Cercis Canadensis L. & Low & 4198 & 1.419 & 3.579 & 3.607 & 2.118 & 3.189 & 2.353 \\
\hline Chamaecyparis thyoides (L.) B.S.P. & Low & 821 & 1.464 & 1.927 & 0.697 & 1.704 & 1.542 & 1.475 \\
\hline Cornus florida $\mathrm{L}$. & Medium & 10,589 & 1.545 & 1.868 & 1.631 & 1.607 & 1.765 & 1.554 \\
\hline Diospyros virginiana L. & Low & 7074 & 1.981 & 8.115 & 8.345 & 4.039 & 7.027 & 4.814 \\
\hline Fagus grandifolia Ehrh. & High & 35,486 & 1.118 & 1.291 & 0.996 & 1.163 & 1.193 & 1.178 \\
\hline Fraxinus Americana L. & Medium & 42,548 & 1.314 & 1.633 & 1.547 & 1.455 & 1.559 & 1.507 \\
\hline Fraxinus nigra Marshall & Medium & 13,276 & 1.114 & 0.934 & 0.890 & 1.080 & 0.955 & 0.997 \\
\hline Fraxinus pennsylvanica Marshall & Low & 47,622 & 1.872 & 2.747 & 2.738 & 2.200 & 2.627 & 2.413 \\
\hline Fraxinus quadrangulata Michx. & Low & 631 & 0.870 & 1.045 & 0.709 & 0.888 & 0.889 & 0.827 \\
\hline Gleditsia triacanthos L. & Low & 11,912 & 1.317 & 3.096 & 3.083 & 1.907 & 2.739 & 2.078 \\
\hline Gordonia lasianthus (L.) Ellis & Medium & 2418 & 1.666 & 1.812 & 1.567 & 1.651 & 1.712 & 1.549 \\
\hline Halesia spp. & Low & 150 & 1.354 & 1.627 & 1.314 & 1.486 & 1.518 & 1.391 \\
\hline Ilex opaca Aiton & Medium & 5391 & 1.829 & 2.456 & 2.165 & 2.018 & 2.304 & 1.956 \\
\hline Juglans nigra $\mathrm{L}$. & Low & 24,037 & 1.282 & 2.367 & 2.081 & 1.678 & 2.069 & 1.873 \\
\hline Juniperus ashei J. Buchholz & High & 21,113 & 1.334 & 3.632 & 7.938 & 1.863 & 4.673 & 3.268 \\
\hline Juniperus virginiana $\mathrm{L}$. & Medium & 49,834 & 1.794 & 3.717 & 3.864 & 2.524 & 3.508 & 3.016 \\
\hline Larix laricina (Du Roi) K. Koch & High & 12,797 & 1.198 & 1.170 & 1.161 & 1.238 & 1.215 & 1.176 \\
\hline Liquidambar styraciflua L. & High & 91,344 & 1.342 & 1.816 & 1.802 & 1.479 & 1.730 & 1.604 \\
\hline Liriodendron tulipifera $\mathrm{L}$. & High & 63,276 & 0.895 & 0.821 & 0.645 & 0.807 & 0.766 & 0.786 \\
\hline Maclura pomifera (Raf.) Schneid. & Medium & 11,988 & 1.167 & 2.920 & 2.610 & 1.755 & 2.408 & 1.883 \\
\hline
\end{tabular}


Table A1. Cont.

\begin{tabular}{|c|c|c|c|c|c|c|c|c|}
\hline Scientific Name & $\begin{array}{c}\text { Model } \\
\text { Reliability }\end{array}$ & $\begin{array}{c}\text { FIA } \\
\text { sumIV }\end{array}$ & CCSM45 & GFDL85 & HAD85 & GCM45 & GCM85 & GCMave \\
\hline Magnolia acuminata L. & Low & 1734 & 1.058 & 1.106 & 1.066 & 1.039 & 1.086 & 1.008 \\
\hline Magnolia fraseri Walter & Low & 651 & 1.542 & 1.667 & 1.610 & 1.540 & 1.653 & 1.465 \\
\hline Magnolia grandiflora L. & Low & 1407 & 5.634 & 11.214 & 3.819 & 6.490 & 8.227 & 6.387 \\
\hline Magnolia macrophylla Michx. & Low & 292 & 0.891 & 0.979 & 0.678 & 0.879 & 0.889 & 0.823 \\
\hline Magnolia virginiana $\mathrm{L}$. & Medium & 7875 & 2.622 & 3.793 & 1.945 & 2.798 & 3.129 & 2.658 \\
\hline Morus rubra L. & Low & 8905 & 1.432 & 3.160 & 1.991 & 1.955 & 2.345 & 1.904 \\
\hline Nyssa aquatic L. & Medium & 5014 & 1.284 & 1.856 & 1.215 & 1.377 & 1.587 & 1.360 \\
\hline Nyssa biflora Walter & Medium & 14,558 & 1.716 & 2.140 & 1.813 & 1.816 & 1.991 & 1.760 \\
\hline Nyssa sylvatica Marshall & Medium & 25,962 & 1.772 & 2.576 & 2.449 & 2.037 & 2.450 & 2.243 \\
\hline Ostrya virginiana (Mill.) K.Koch & Low & 12,225 & 2.107 & 3.507 & 2.670 & 2.599 & 3.017 & 2.500 \\
\hline Oxydendrum arboretum (L.) DC. & High & 11,224 & 1.020 & 0.911 & 0.701 & 0.885 & 0.860 & 0.877 \\
\hline Persea borbonia (L.) Spreng. & Low & 2757 & 1.729 & 2.491 & 1.563 & 1.839 & 2.078 & 1.776 \\
\hline Picea glauca (Moench) Voss & Medium & 7764 & 0.758 & 0.844 & 0.863 & 0.778 & 0.842 & 0.807 \\
\hline $\begin{array}{l}\text { Picea mariana (Mill.) Britton, } \\
\text { Sterns \& Poggenburg }\end{array}$ & High & 14,500 & 0.497 & 0.468 & 0.453 & 0.474 & 0.460 & 0.534 \\
\hline Picea rubens Sarg. & High & 13,049 & 0.689 & 0.556 & 0.554 & 0.612 & 0.555 & 0.637 \\
\hline Pinus banksiana Lamb. & Medium & 9280 & 0.719 & 0.635 & 0.642 & 0.689 & 0.661 & 0.702 \\
\hline $\begin{array}{l}\text { Pinus clausa (Chapm. ex } \\
\text { Engelm.) Sarg. }\end{array}$ & Medium & 3740 & 1.223 & 1.573 & 0.850 & 1.413 & 1.275 & 1.263 \\
\hline Pinus echinata Mill. & High & 32,601 & 2.147 & 3.848 & 3.985 & 2.796 & 3.665 & 3.231 \\
\hline Pinus elliottii Engelm. & High & 57,498 & 1.450 & 2.093 & 1.622 & 1.577 & 1.858 & 1.718 \\
\hline Pinus glabra Walter & Low & 1039 & 0.507 & 0.608 & 0.297 & 0.551 & 0.487 & 0.533 \\
\hline Pinus palustris Mill. & Medium & 19,920 & 2.677 & 4.428 & 2.167 & 2.933 & 3.507 & 3.220 \\
\hline Pinus pungens Lamb. & Low & 527 & 0.798 & 1.297 & 1.541 & 1.061 & 1.246 & 1.061 \\
\hline Pinus resinosa Sol. ex Aiton & Medium & 17,992 & 0.945 & 0.967 & 0.937 & 0.998 & 0.973 & 0.985 \\
\hline Pinus rigida Mill. & High & 5653 & 0.754 & 0.948 & 0.982 & 0.818 & 0.928 & 0.854 \\
\hline Pinus serotina Michx. & Medium & 4019 & 1.471 & 1.569 & 1.203 & 1.335 & 1.448 & 1.298 \\
\hline Pinus strobus L. & High & 42,529 & 1.137 & 0.882 & 0.827 & 1.090 & 0.921 & 1.006 \\
\hline Pinus taeda L. & High & 271,571 & 1.178 & 1.404 & 1.285 & 1.212 & 1.324 & 1.268 \\
\hline Pinus virginiana Mill. & High & 21,514 & 0.915 & 0.933 & 0.888 & 0.843 & 0.913 & 0.878 \\
\hline Planera aquatic J.F.Gmel. & Low & 932 & 1.940 & 3.579 & 4.961 & 2.526 & 3.987 & 2.854 \\
\hline Platanus occidentalis L. & Low & 11,992 & 1.963 & 4.698 & 4.200 & 2.803 & 4.053 & 3.030 \\
\hline Populus balsamifera L. & Medium & 5854 & 0.431 & 0.314 & 0.423 & 0.380 & 0.385 & 0.445 \\
\hline $\begin{array}{c}\text { Populus deltoids W.Bartram ex } \\
\text { Marshall }\end{array}$ & Low & 11,742 & 1.935 & 4.570 & 3.983 & 2.881 & 4.034 & 3.034 \\
\hline Populus grandidentata Michaux & Medium & 12,814 & 1.218 & 1.034 & 0.974 & 1.235 & 1.074 & 1.094 \\
\hline Populus tremuloides Michx. & High & 54,642 & 0.814 & 0.671 & 0.636 & 0.775 & 0.691 & 0.733 \\
\hline Prunus pensylvanica L.f. & Low & 1734 & 0.354 & 0.132 & 0.151 & 0.284 & 0.164 & 0.259 \\
\hline Prunus serotina Ehr. & Medium & 60,388 & 1.380 & 1.529 & 1.404 & 1.477 & 1.466 & 1.472 \\
\hline Quercus alba L. & Medium & 87,470 & 1.225 & 1.364 & 1.300 & 1.317 & 1.330 & 1.324 \\
\hline Quercus bicolor Willd. & Low & 2188 & 1.833 & 3.550 & 2.420 & 2.713 & 3.077 & 2.549 \\
\hline Quercus coccinea Muenchh. & Medium & 17,739 & 1.128 & 1.221 & 1.137 & 1.168 & 1.208 & 1.188 \\
\hline Quercus ellipsoidalis E.J.Hill & Medium & 6120 & 1.679 & 1.915 & 1.454 & 1.909 & 1.733 & 1.677 \\
\hline Quercus falcate Michx. & Medium & 24,747 & 2.091 & 3.581 & 4.291 & 2.697 & 3.659 & 3.178 \\
\hline Quercus imbricaria Michx. & Medium & 4356 & 0.680 & 0.802 & 0.516 & 0.772 & 0.635 & 0.704 \\
\hline Quercus incana Bartram & Low & 624 & 1.050 & 3.781 & 9.120 & 2.678 & 5.097 & 3.404 \\
\hline Quercus laevis Walter & Medium & 2731 & 1.205 & 1.590 & 1.009 & 1.258 & 1.327 & 1.211 \\
\hline Quercus laurifolia Michx. & Medium & 15,945 & 1.947 & 2.739 & 1.708 & 2.046 & 2.263 & 1.974 \\
\hline Quercus lyrata Walter & Medium & 4159 & 1.589 & 3.426 & 3.826 & 2.166 & 3.289 & 2.435 \\
\hline Quercus macrocarpa Michx. & Medium & 19,711 & 1.705 & 1.941 & 1.592 & 1.859 & 1.816 & 1.837 \\
\hline Quercus marilandica Muenchh. & Medium & 10,061 & 2.750 & 10.400 & 11.679 & 5.241 & 9.588 & 6.459 \\
\hline Quercus michauxii Nutt. & Low & 2156 & 2.111 & 3.834 & 2.445 & 2.643 & 3.098 & 2.531 \\
\hline Quercus muehlenbergii Engelm. & Medium & 6459 & 1.230 & 2.054 & 1.388 & 1.484 & 1.613 & 1.433 \\
\hline Quercus nigra $\mathrm{L}$. & High & 46,637 & 2.089 & 3.282 & 3.325 & 2.568 & 3.195 & 2.882 \\
\hline Quercus pagoda Raf. & Medium & 7681 & 2.027 & 3.388 & 3.255 & 2.470 & 3.199 & 2.539 \\
\hline Quercus palustris Münchh. & Low & 4434 & 0.974 & 2.846 & 1.892 & 1.347 & 1.970 & 1.510 \\
\hline Quercus phellos L. & Low & 10,282 & 2.116 & 3.299 & 3.727 & 2.625 & 3.336 & 2.653 \\
\hline Quercus prinus Willd. & High & 34,675 & 1.186 & 1.270 & 1.177 & 1.191 & 1.233 & 1.212 \\
\hline Quercus rubra L. & Medium & 55,330 & 1.410 & 1.460 & 1.337 & 1.478 & 1.416 & 1.447 \\
\hline Quercus shumardii Buckland & Low & 2523 & 1.127 & 5.424 & 4.020 & 2.050 & 3.989 & 2.664 \\
\hline Quercus stellate Wangenh. & High & 58,812 & 2.169 & 4.671 & 5.252 & 3.077 & 4.504 & 3.791 \\
\hline Quercus texana Buckley & Low & 2363 & 1.282 & 1.681 & 1.597 & 1.361 & 1.589 & 1.353 \\
\hline Quercus velutina Lam. & High & 44,550 & 1.598 & 2.469 & 2.301 & 1.962 & 2.273 & 2.118 \\
\hline Quercus virginiana Mill. & High & 25,609 & 2.450 & 7.093 & 10.064 & 3.789 & 7.552 & 5.670 \\
\hline Robinia pseudoacacia L. & Low & 18,414 & 1.380 & 3.449 & 3.471 & 1.922 & 3.030 & 2.476 \\
\hline Sabal palmetto (Walt.) Lodd. & Medium & 4949 & 2.046 & 3.867 & 2.557 & 2.337 & 3.123 & 2.473 \\
\hline Salix nigra Marshall & Low & 13,959 & 1.445 & 4.936 & 5.616 & 2.458 & 4.558 & 3.075 \\
\hline Sassafras albidum (Nutt.) Nees & Low & 14,728 & 1.477 & 2.377 & 2.631 & 1.871 & 2.346 & 1.908 \\
\hline $\begin{array}{c}\text { Sideroxylon lanuginosum ssp. } \\
\text { lanuginosum }\end{array}$ & Low & 2109 & 7.622 & 49.696 & 89.291 & 23.994 & 56.912 & 34.731 \\
\hline Sorbus Americana Marshall & Low & 147 & 0.397 & 0.265 & 0.292 & 0.334 & 0.282 & 0.330 \\
\hline Taxodium ascendens Brongn. & Medium & 8177 & 2.305 & 4.612 & 2.979 & 2.467 & 3.457 & 2.646 \\
\hline
\end{tabular}


Table A1. Cont.

\begin{tabular}{|c|c|c|c|c|c|c|c|c|}
\hline Scientific Name & $\begin{array}{c}\text { Model } \\
\text { Reliability }\end{array}$ & $\begin{array}{c}\text { FIA } \\
\text { sumIV }\end{array}$ & CCSM45 & GFDL85 & HAD85 & GCM45 & GCM85 & GCMave \\
\hline Taxodium distichum (L.) Rich. & Medium & 8683 & 2.324 & 3.622 & 2.692 & 2.599 & 3.131 & 2.558 \\
\hline Thuja occidentalis L. & High & 20,487 & 0.808 & 0.854 & 0.975 & 0.818 & 0.926 & 0.872 \\
\hline Tilia americana $\mathrm{L}$. & Medium & 20,151 & 1.432 & 1.385 & 1.196 & 1.496 & 1.336 & 1.416 \\
\hline Tsuga Canadensis (L.) Carrière & High & 27,300 & 1.035 & 0.724 & 0.707 & 0.926 & 0.765 & 0.846 \\
\hline Ulmus alata Michx. & Medium & 21,303 & 2.273 & 4.353 & 5.729 & 3.137 & 4.597 & 3.867 \\
\hline Ulmus americana L. & Medium & 55,590 & 1.475 & 2.316 & 2.401 & 1.799 & 2.218 & 2.008 \\
\hline Ulmus crassifolia Nutt. & Medium & 8062 & 3.431 & 14.046 & 23.482 & 7.557 & 15.895 & 10.167 \\
\hline Ulmus rubra Muhl. & Low & 13,179 & 1.359 & 2.543 & 2.828 & 1.774 & 2.453 & 1.907 \\
\hline
\end{tabular}
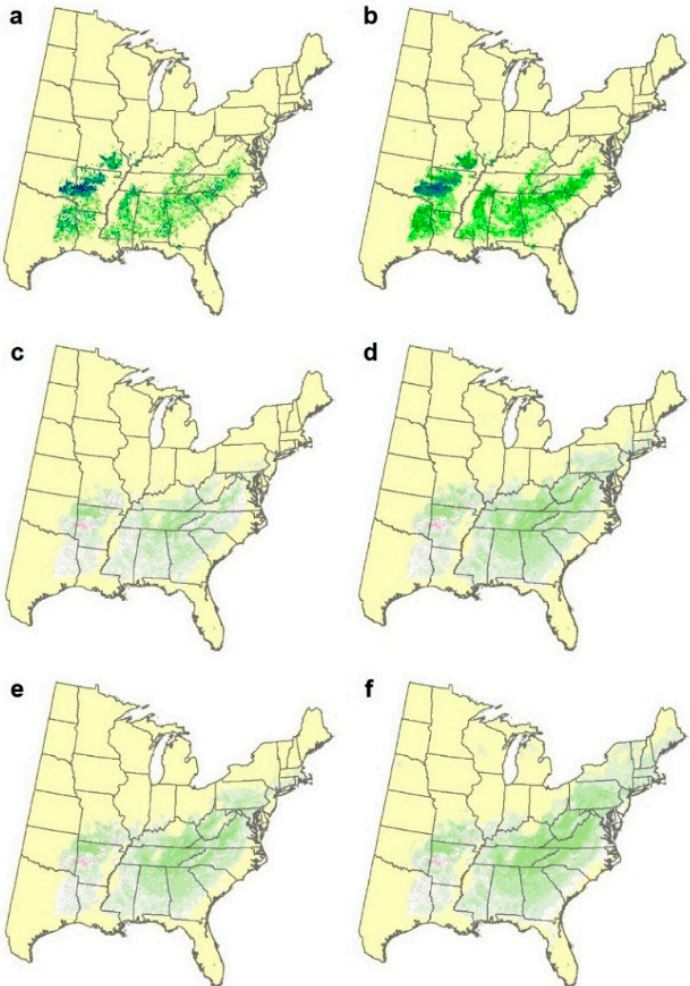

g
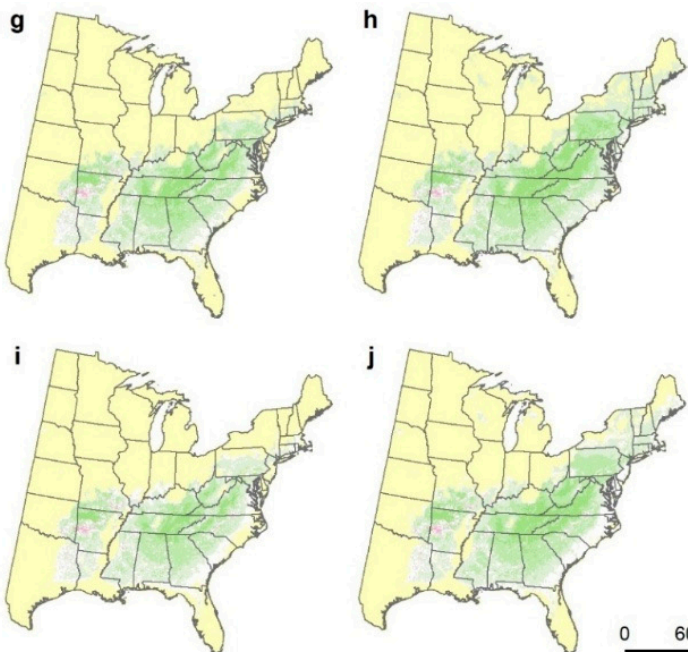

b

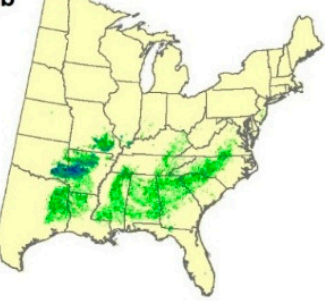

d

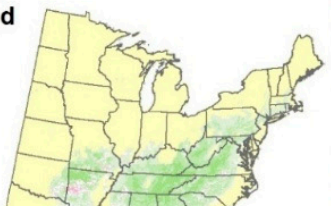

Value

$<-20.0$

$-20.0--10.1$

$-10.0--5.1$

$-5.0--2.0$

$-1.9-1.9$

$2.0-5.0$

$5.1-10.0$

$>10.0$

Not Modeled

Not Suitable

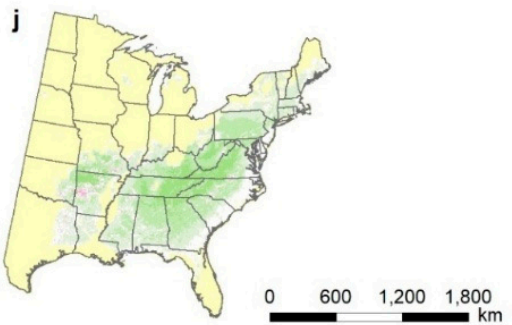

Figure A1. Species distributions for Pinus echinata (shortleaf pine), shown as differences from current modeled distribution (map b): (a) FIA estimate of current distribution of abundance, (b) modeled current distribution, (c) CCSM45, (d) CCSM85, (e) GFDL45, (f) GFDL85, (g) Had45, (h) Had85, (i) mean of all three RCP4.5, and (j) mean of all three RCP8.5. 
a

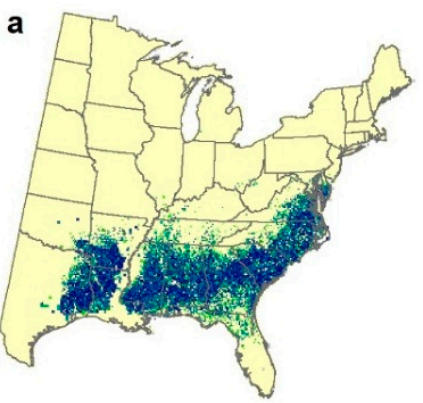

C

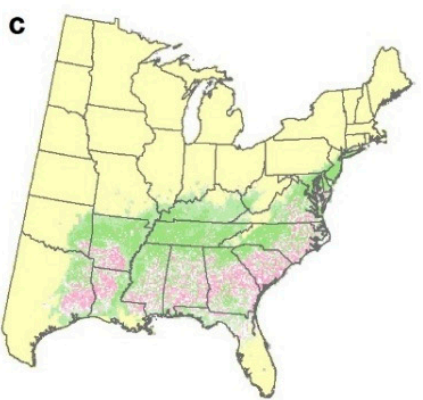

e

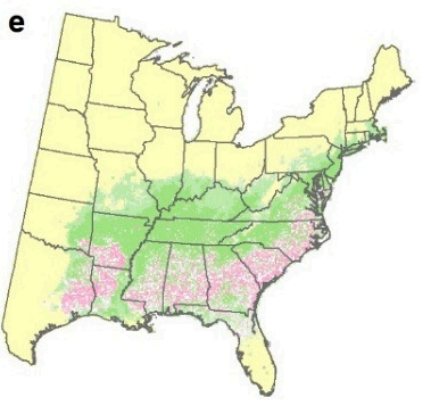

g
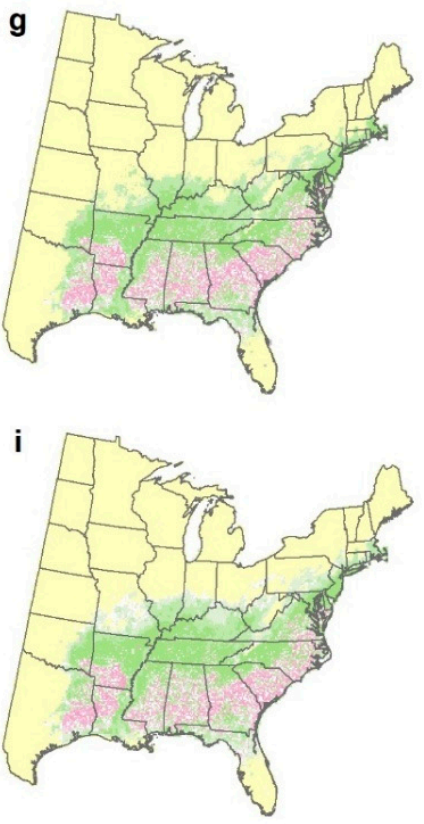

b

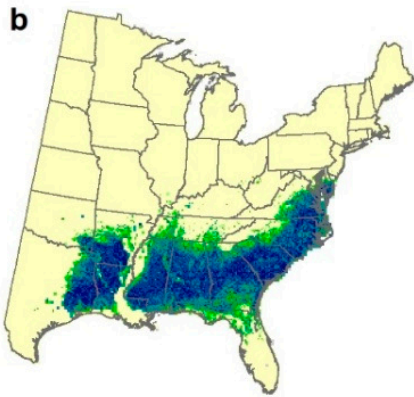

Importance

Value

No Data

0

1 - 3

$4-6$

$7-10$

$11-20$

$21-30$

$31-50$

$51-100$

Change in

Importance

Value

$<-20.0$

$-20.0--10.1$

$-10.0--5.1$

$-5.0--2.0$

$-1.9-1.9$

$2.0-5.0$

$5.1-10.0$

$>10.0$

Not Modeled

Not Suitable
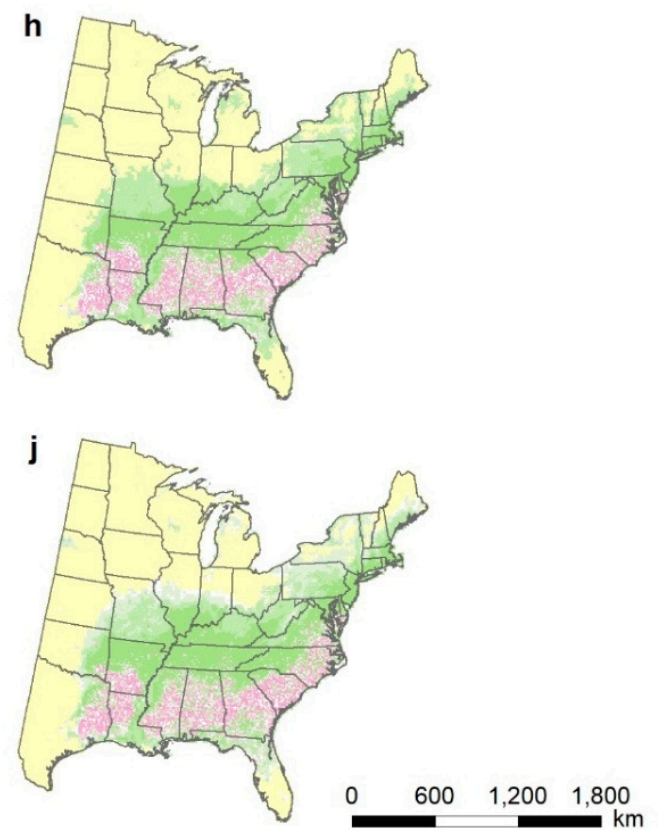

Figure A2. Species distributions for Pinus teada (loblolly pine), shown as differences from current modeled distribution (map b): (a) FIA estimate of current distribution of abundance, (b) modeled current distribution, (c) CCSM45, (d) CCSM85, (e) GFDL45, (f) GFDL85, (g) Had45, (h) Had85, (i) mean of all three RCP4.5, and (j) mean of all three RCP8.5. 

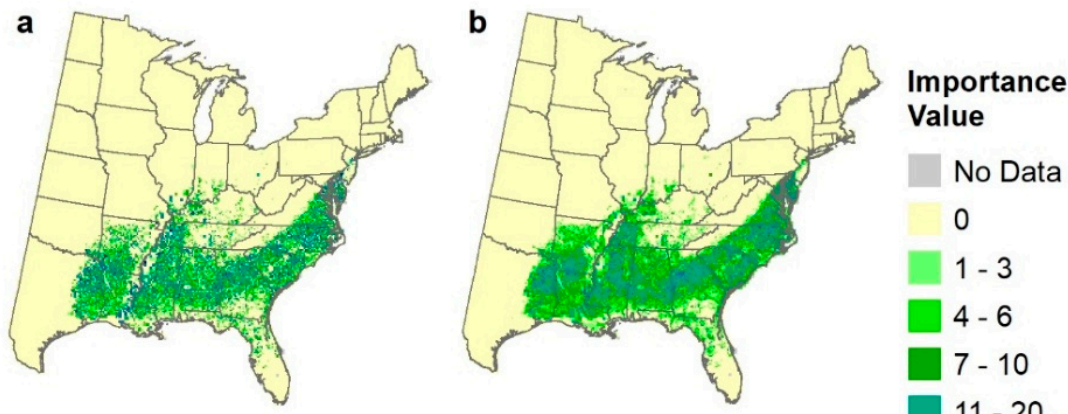

Value
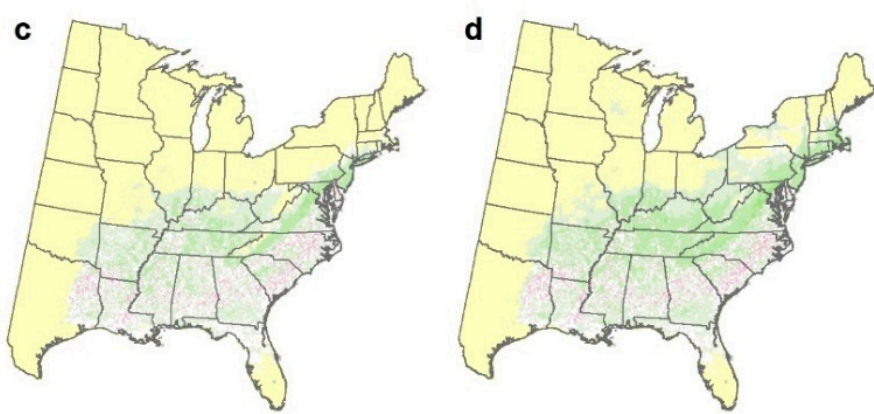

No Data
0
1 - 3
$4-6$
7 - 10
$11-20$

$11-20$

$21-30$

- $31-50$

$51-100$

Change in Importance

Value

$<-20.0$

$-20.0--10.1$

$-10.0--5.1$

e

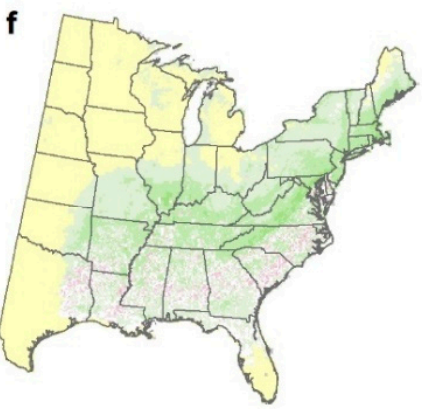

$-5.0--2.0$

$-1.9-1.9$

$2.0-5.0$

$5.1-10.0$

$>10.0$

Not Modeled

Not Suitable
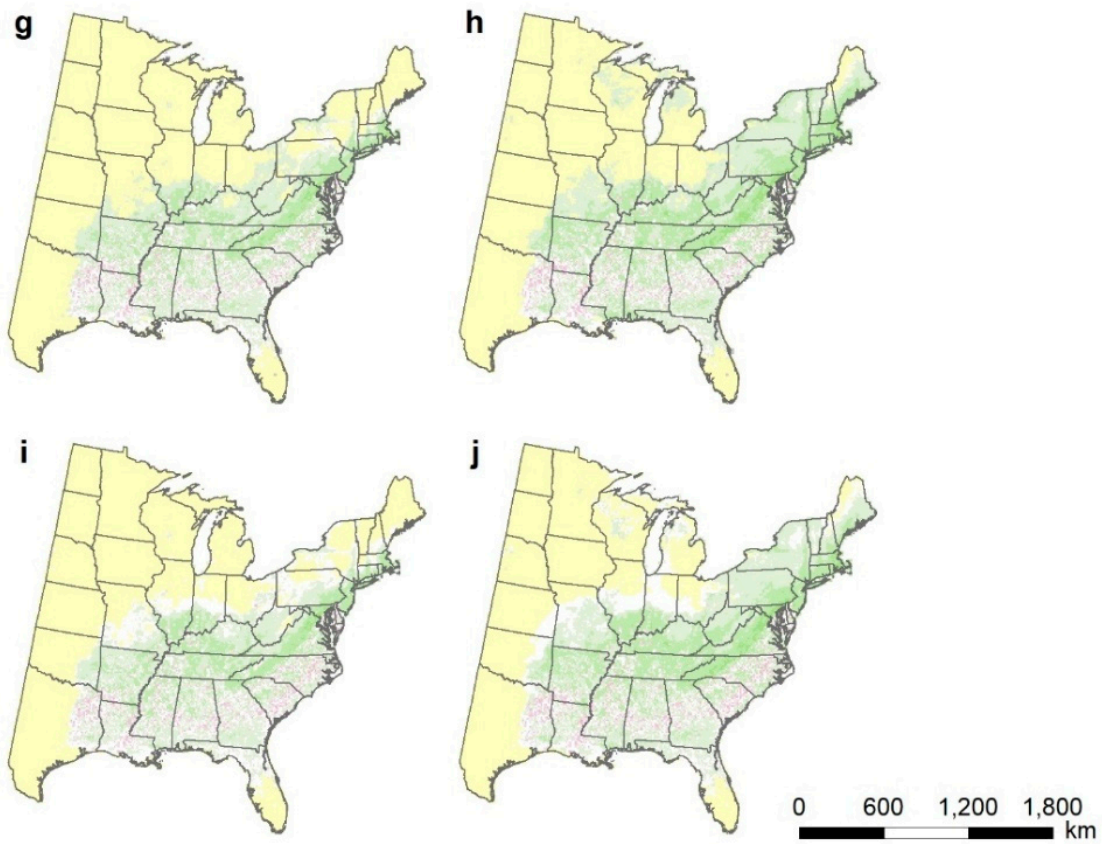

Figure A3. Species distributions for Liquidambar styraciflua (sweetgum), shown as differences from current modeled distribution (map b): (a) FIA estimate of current distribution of abundance, (b) modeled current distribution, (c) CCSM45, (d) CCSM85, (e) GFDL45, (f) GFDL85, (g) Had45, (h) Had85, (i) mean of all three RCP4.5, and (j) mean of all three RCP8.5. 


\section{References}

1. Mora, C.; Spirandelli, D.; Franklin, E.C.; Lynham, J.; Kantar, M.B.; Miles, W.; Smith, C.Z.; Freel, K.; Moy, J.; Louis, L.V.; et al. Broad threat to humanity from cumulative climate hazards intensified by greenhouse gas emissions. Nat. Clim. Chang. 2018. [CrossRef]

2. Hsiang, S.; Kopp, R.; Jina, A.; Rising, J.; Delgado, M.; Mohan, S.; Rasmussen, D.J.; Muir-Wood, R.; Wilson, P.; Oppenheimer, M.; et al. Estimating economic damage from climate change in the United States. Science 2017, 356, 1362-1369. [CrossRef] [PubMed]

3. IPCC Summary for Policymakers. In Global Warming of $1.5^{\circ} \mathrm{C}$. An IPCC Special Report on the Impacts of Global Warming of $1.5^{\circ} \mathrm{C}$ Above Pre-Industrial Levels and Related Global Greenhouse Gas Emission Pathways, in the Context of Strengthening the Global Response to the Threat of Climate Change, Sustainable Development, and Efforts to Eradicate Poverty; World Meteorological Organization: Geneva, Switzerland, 2018; p. 32.

4. Rogelj, J.; den Elzen, M.; Höhne, N.; Fransen, T.; Fekete, H.; Winkler, H.; Schaeffer, R.; Sha, F.; Riahi, K.; Meinshausen, M. Paris Agreement climate proposals need a boost to keep warming well below $2{ }^{\circ} \mathrm{C}$. Nature 2016, 534, 631. [CrossRef] [PubMed]

5. Warren, R.; Price, J.; Graham, E.; Forstenhaeusler, N.; VanDerWal, J. The projected effect on insects, vertebrates, and plants of limiting global warming to $1.5^{\circ} \mathrm{C}$ rather than $2{ }^{\circ} \mathrm{C}$. Science 2018, 360, 791-795. [CrossRef]

6. Swanston, C.W.; Janowiak, M.; Brandt, L.; Butler, P.; Handler, S.D.; Shannon, P.D.; Lewis, A.D.; Hall, K.R.; Fahey, R.T.; Scott, L.; et al. Forest Adaptation Resources: Climate Change Tools and Approaches for Land Managers, 2nd ed.; Gen. Tech. Rep. NRS-GTR-87-2; U.S. Department of Agriculture, Forest Service, Northern Research Station: Newtown Square, PA, USA, 2016; p. 161.

7. Millar, C.; Stephenson, N.L. Climate change and forests of the future: Managing in the face of uncertainty. Ecol. Appl. 2007, 17, 2145-2151. [CrossRef] [PubMed]

8. Nagel, L.M.; Palik, B.J.; Battaglia, M.A.; D'Amato, A.W.; Guldin, J.M.; Swanston, C.W.; Janowiak, M.K.; Powers, M.P.; Joyce, L.A.; Millar, C.I.; et al. Adaptive Silviculture for Climate Change: A National Experiment in Manager-Scientist Partnerships to Apply an Adaptation Framework. J. For. 2017, 115, 167-178. [CrossRef]

9. Halofsky, J.E.; Andrews-Key, S.A.; Edwards, J.E.; Johnston, M.H.; Nelson, H.W.; Peterson, D.L.; Schmitt, K.M.; Swanston, C.W.; Williamson, T.B. Adapting forest management to climate change: The state of science and applications in Canada and the United States. For. Ecol. Manag. 2018, 421, 84-97. [CrossRef]

10. Iverson, L.; McKenzie, D. Tree-species range shifts in a changing climate-Detecting, modeling, assisting. Landsc. Ecol. 2013, 28, 879-889. [CrossRef]

11. Lenoir, J.; Svenning, J.C. Climate-related range shifts-A global multidimensional synthesis and new research directions. Ecography 2014, 38, 15-28. [CrossRef]

12. Vanderwel, M.C.; Rozendaal, D.M.A.; Evans, M.E.K. Predicting the abundance of forest types across the eastern U.S. through inverse modelling of tree demography. Ecol. Appl. 2017, 27, 2128-2141. [CrossRef]

13. Clark, J.S.; Nemergut, D.; Seyednasrollah, B.; Turner, P.J.; Zhang, S. Generalized joint attribute modeling for biodiversity analysis: Median-zero, multivariate, multifarious data. Ecol. Monogr. 2016, 87, 34-56. [CrossRef]

14. DeHayes, D.H.; Jacobson, G.L.; Schaberg, P.G.; Bongarten, B.; Iverson, L.R.; Dieffenbacker-Krall, A. Forest responses to changing climate: Lessons from the past and uncertainty for the future. In Responses of Northern Forests to Environmental Change; Mickler, R.A., Birdsey, R.A., Hom, J.L., Eds.; Springer, Ecological Studies Series: New York, NY, USA, 2000; pp. 495-540.

15. Delcourt, P.A.; Delcourt, H.R. Late-Quaternary dynamics of temperate forests-Applications of paleoecology to issues of global environmental-change. Quat. Sci. Rev. 1987, 6, 129-146. [CrossRef]

16. Koo, K.A.; Madden, M.; Patten, B.C. Projection of red spruce (Picea rubens Sargent) habitat suitability and distribution in the Southern Appalachian Mountains, USA. Ecol. Model. 2014, 293, 91-101. [CrossRef]

17. Prasad, A.M.; Iverson, L.R.; Matthews, S.N.; Peters, M.P. A multistage decision support framework to guide tree species management under climate change via habitat suitability and colonization models, and a knowledge-based scoring system. Landsc. Ecol. 2016, 31, 2187-2204. [CrossRef]

18. Iverson, L.; Prasad, A.M.; Matthews, S.; Peters, M. Lessons learned while integrating habitat, dispersal, disturbance, and life-history traits into species habitat models under climate change. Ecosystems 2011, 14, 1005-1020. [CrossRef] 
19. Morin, X.; Thuiller, W. Comparing niche- and process-based models to reduce prediction uncertainty in species range shifts under climate change. Ecology 2009, 90, 1301-1313. [CrossRef] [PubMed]

20. Iverson, L.R.; Thompson, F.R.; Matthews, S.; Peters, M.; Prasad, A.; Dijak, W.D.; Fraser, J.; Wang, W.J.; Hanberry, B.; He, H.; et al. Multi-model comparison on the effects of climate change on tree species in the eastern U.S.: Results from an enhanced niche model and process-based ecosystem and landscape models. Landsc. Ecol. 2017, 32, 1327-1346. [CrossRef]

21. Johnstone, J.F.; Allen, C.D.; Franklin, J.F.; Frelich, L.E.; Harvey, B.J.; Higuera, P.E.; Mack, M.C.; Meentemeyer, R.K.; Metz, M.R.; Perry, G.L.; et al. Changing disturbance regimes, ecological memory, and forest resilience. Front. Ecol. Environ. 2016, 14, 369-378. [CrossRef]

22. Kullman, L. Rapid recent range-margin rise of tree and shrub species in the Swedish Scandes. J. Ecol. 2002, 90, 68-77. [CrossRef]

23. Gamache, I.; Payette, S. Latitudinal response of subarctic tree lines to recent climate change in eastern Canada. J. Biogeogr. 2005, 32, 849-862. [CrossRef]

24. Holzinger, B.; Hulber, K.; Camenisch, M.; Grabherr, G. Changes in plant species richness over the last century in the eastern Swiss Alps: Elevational gradient, bedrock effects and migration rates. Plant Ecol. 2008, 195, 179-196. [CrossRef]

25. Lenoir, J.; Gégout, J.C.; Marquet, P.A.; de Ruffray, P.; Brisse, H. A significant upward shift in plant species optimum elevation during the 20th century. Science 2008, 320, 1768-1771. [CrossRef]

26. Hillyer, R.; Silman, M.R. Changes in species interactions across a $2.5 \mathrm{~km}$ elevation gradient: Effects on plant migration in response to climate change. Glob. Chang. Biol. 2010, 16, 3205-3214. [CrossRef]

27. Felde, V.A.; Kapfer, J.; Grytnes, J.-A. Upward shift in elevational plant species ranges in Sikkilsdalen, central Norway. Ecography 2012, 35, 922-932. [CrossRef]

28. Freeman, B.G.; Lee-Yaw, J.A.; Sunday, J.M.; Hargreaves, A.L. Expanding, shifting and shrinking: The impact of global warming on species' elevational distributions. Glob. Ecol. Biogeogr. 2018, 27, 1268-1276. [CrossRef]

29. Foster, J.R.; D'Amato, A.W. Montane forest ecotones moved downslope in northeastern US in spite of warming between 1984 and 2011. Glob. Chang. Biol. 2015, 21, 4497-4507. [CrossRef] [PubMed]

30. Beckage, B.; Osborne, B.; Gavin, D.G.; Pucko, C.; Siccama, T.; Perkins, T. A rapid upward shift of a forest ecotone during 40 years of warming in the Green Mountains of Vermont. Proc. Natl. Acad. Sci. USA 2008, 105, 4197-4202. [CrossRef]

31. Morin, R.S.; Liebhold, A.M. Invasive forest defoliator contributes to the impending downward trend of oak dominance in eastern North America. For. Int. J. For. Res. 2015, 89, 284-289. [CrossRef]

32. Dolan, B.K.J. Forest regeneration following emerald ash borer (Agrilus planipennis Fairemaire) enhances mesophication in eastern hardwood forests. Forests 2018, 9, 353. [CrossRef]

33. Wang, W.; He, H.; Thompson, F., III; Fraser, J.; Hanberry, B.; Dijak, W. The importance of succession, harvest, and climate change in determining future forest composition changes in U.S. Central Hardwood Forests. Ecosphere 2015, 6, art277. [CrossRef]

34. Hanberry, B.B.; Hansen, M.H. Latitudinal range shifts of tree species in the United States across multi-decadal time scales. Basic Appl. Ecol. 2015, 16, 231-238. [CrossRef]

35. Boisvert-Marsh, L.; Périé, C.; de Blois, S. Shifting with climate? Evidence for recent changes in tree species distribution at high latitudes. Ecosphere 2014, 5, 1-33. [CrossRef]

36. Boisvert-Marsh, L.; Périé, C.; de Blois, S. Divergent responses to climate change and disturbance drive recruitment patterns underlying latitudinal shifts of tree species. J. Ecol. 2019. [CrossRef]

37. Sittaro, F.; Paquette, A.; Messier, C.; Nock Charles, A. Tree range expansion in eastern North America fails to keep pace with climate warming at northern range limits. Glob. Chang. Biol. 2017, 23, 3292-3301. [CrossRef]

38. Woodall, C.W.; Westfall, J.A.; D'Amato, A.W.; Foster, J.R.; Walters, B.F. Decadal changes in tree range stability across forests of the eastern U.S. For. Ecol. Manag. 2018, 429, 503-510. [CrossRef]

39. Iverson, L.R.; Prasad, A.M. Predicting abundance of 80 tree species following climate change in the eastern United States. Ecol. Monogr. 1998, 68, 465-485. [CrossRef]

40. Iverson, L.R.; Prasad, A.M.; Hale, B.J.; Sutherland, E.K. Atlas of Current and Potential Future Distributions of Common Trees of the Eastern United States; General Technical Report NE-265; Northeastern Research Station, USDA Forest Service: Radnor, PA, USA, 1999; p. 245.

41. Prasad, A.M.; Iverson, L.R.; Liaw, A. Newer classification and regression tree techniques: Bagging and random forests for ecological prediction. Ecosystems 2006, 9, 181-199. [CrossRef] 
42. Iverson, L.R.; Prasad, A.M.; Matthews, S.N.; Peters, M. Estimating potential habitat for 134 eastern US tree species under six climate scenarios. For. Ecol. Manag. 2008, 254, 390-406. [CrossRef]

43. Iverson, L.R.; Prasad, A.M.; Matthews, S.N. Modeling potential climate change impacts on the trees of the northeastern United States. Mitig. Adapt. Strateg. Glob. Chang. 2008, 13, 487-516. [CrossRef]

44. Butler-Leopold, P.R.; Iverson, L.R.; Thompson, F.R., III; Brandt, L.A.; Handler, S.D.; Janowiak, M.K.; Shannon, P.D.; Swanston, C.W.; Bearer, S.; Bryan, A.M.; et al. Mid-Atlantic Forest Ecosystem Vulnerability Assessment and Synthesis: A Report from the Mid-Atlantic Climate Change Response Framework Project; Gen. Tech. Rep. NRS-181; U.S. Department of Agriculture, Forest Service, Northern Research Station: Newtown Square, PA, USA, 2018; p. 365.

45. Butler, P.R.; Iverson, L.; Thompson, F.R.; Brandt, L.; Handler, S.; Janowiak, M.; Shannon, P.D.; Swanston, C.; Karriker, K.; Bartig, J.; et al. Central Appalachians Forest Ecosystem Vulnerability Assessment and Synthesis: A Report from the Central Appalachians Climate Change Response Framework Project; U.S. Department of Agriculture, Forest Service, Northern Research Station: Newtown Square, PA, USA, 2015; p. 310.

46. Brandt, L.; He, H.; Iverson, L.; Thompson, F.; Butler, P.; Handler, S.; Janowiak, M.; Swanston, C.; Albrecht, M.; Blume-Weaver, R.; et al. Central Hardwoods Ecosystem Vulnerability Assessment and Synthesis: A Report from the Central Hardwoods Climate Change Response Framework Project; U.S. Department of Agriculture, Forest Service, Northern Research Station: Newtown Square, PA, USA, 2014; p. 254.

47. Handler, S.; Duveneck, M.; Iverson, L.; Peters, E.; Scheller, R.; Wythers, K.; Brandt, L.; Butler, P.; Janowiak, M.; Swanston, C.; et al. Minnesota Forest Ecosystem Vulnerability Assessment and Synthesis: A report from the Northwoods Climate Change Response Framework; Gen. Tech. Rep. NRS-133; U.S. Department of Agriculture, Forest Service, Northern Research Station: Newtown Square, PA, USA, 2014.

48. Handler, S.; Duveneck, M.J.; Iverson, L.; Peters, E.; Scheller, R.; Wythers, K.; Brandt, L.; Butler, P.; Janowiak, M.; Swanston, C.; et al. Michigan Forest Ecosystem Vulnerability Assessment and Synthesis: A Report from the Northwoods Climate Change Response Framework; Gen. Tech. Rep. NRS-129; U.S. Department of Agriculture, Forest Service, Northern Research Station: Newtown Square, PA, USA, 2014.

49. Janowiak, M.K.; Iverson, L.R.; Mladenoff, D.J.; Peters, E.; Wythers, K.R.; Xi, W.; Brandt, L.A.; Butler, P.R.; Handler, S.D.; Shannon, P.D.; et al. Forest Ecosystem Vulnerability Assessment and Synthesis for Northern Wisconsin and Western Upper Michigan: A Report from the Northwoods Climate Change Response Framework Project; Gen. Tech. Rep. NRS-136; U.S. Department of Agriculture, Forest Service, Northern Research Station: Newtown Square, PA, USA, 2014; p. 247.

50. Janowiak, M.K.; D'Amato, A.W.; Swanston, C.W.; Iverson, L.; Thompson, F., III; Dijak, W.; Matthews, S.; Peters, M.; Prasad, A.; Fraser, J.; et al. New England and Northern New York Forest Ecosystem Vulnerability Assessment and Synthesis: A Report from the New England Climate Change Response Framework Project; Gen. Tech. Rep. NRS-173; U.S. Department of Agriculture, Forest Service, Northern Research Station: Newtown Square, PA, USA, 2018; p. 234.

51. Brandt, L.A.; Derby Lewis, A.; Scott, L.; Darling, L.; Fahey, R.T.; Iverson, L.; Nowak, D.J.; Bodine, A.R.; Bell, A.; Still, S.; et al. Chicago Wilderness Region Urban Forest Vulnerability Assessment and Synthesis: A Report from the Urban Forestry Climate Change Response Framework Chicago Wilderness Pilot Project; U.S. Department of Agriculture, Forest Service, Northern Research Station: Newtown Square, PA, USA, 2017; p. 142.

52. Soil_Survey_Staff. Gridded Soil Survey Geographic (gSSURGO) Database for Ohio; United States Department of Agriculture, Natural Resources Conservation Service. Available online: https:/ /gdg.sc.egov.usda.gov/ (accessed on 24 May 2016).

53. Daly, C.; Halbleib, M.; Smith, J.I.; Gibson, W.P.; Doggett, M.K.; Taylor, G.H.; Curtis, J.; Pasteris, P.P. Physiographically sensitive mapping of climatological temperature and precipitation across the conterminous United States. Int. J. Climatol. 2008, 28, 2031-2064. [CrossRef]

54. Thrasher, B. Downscaled Climate Projections Suitable for Resource Management. Eos 2013, 94, $321-323$. [CrossRef]

55. Maurer, E.P.; Hidalgo, H.G. Utility of daily vs. monthly large-scale climate data: An intercomparison of two statistical downscaling methods. Hydrol. Earth Syst. Sci. 2008, 12, 551-563. [CrossRef]

56. Monahan, W.B.; Cook, T.; Melton, F.; Connor, J.; Bobowski, B. Forecasting Distributional Responses of Limber Pine to Climate Change at Management-Relevant Scales in Rocky Mountain National Park. PLoS ONE 2013, 8, e83163. [CrossRef] 
57. Moss, R.; Babiker, W.; Brinkman, S.; Calvo, E.; Carter, T.; Edmonds, J.; Elgizouli, I.; Emori, S.; Erda, L.; Hibbard, K. Towards New Scenarios for the Analysis of Emissions, Climate Change, Impacts, and Response Strategies; Intergovernmental Panel on Climate Change: Geneva, Switzerland, 2008; p. 25. ISBN 978-92-9169-124-1.

58. Gent, P.R.; Danabasoglu, G.; Donner, L.J.; Holland, M.M.; Hunke, E.C.; Jayne, S.R.; Lawrence, D.M.; Neale, R.B.; Rasch, P.J.; Vertenstein, M.; et al. The Community Climate System Model Version 4. J. Clim. 2011, 24, 4973-4991. [CrossRef]

59. Donner, L.J.; Wyman, B.L.; Hemler, R.S.; Horowitz, L.W.; Ming, Y.; Zhao, M.; Golaz, J.-C.; Ginoux, P.; Lin, S.J.; Schwarzkopf, M.D.; et al. The Dynamical Core, Physical Parameterizations, and Basic Simulation Characteristics of the Atmospheric Component AM3 of the GFDL Global Coupled Model CM3. J. Clim. 2011, 24, 3484-3519. [CrossRef]

60. Collins, W.J.; Bellouin, N.; Doutriaux-Boucher, M.; Gedney, N.; Halloran, P.; Hinton, T.; Hughes, J.; Jones, C.D.; Joshi, M.; Liddicoat, S.; et al. Development and evaluation of an Earth-System model-HadGEM2. Geosci. Model Dev. 2011, 4, 1051-1075. [CrossRef]

61. Jones, C.D.; Hughes, J.K.; Bellouin, N.; Hardiman, S.C.; Jones, G.S.; Knight, J.; Liddicoat, S.; O'Connor, F.M.; Andres, R.J.; Bell, C.; et al. The HadGEM2-ES implementation of CMIP5 centennial simulations. Geosci. Model Dev. 2011, 4, 543-570. [CrossRef]

62. Peters, M.P.; Iverson, L. Projected Drought for the Conterminous United States in the 21st Century. In Drought Impacts on U.S. Forests and Rangelands: Translating Science into Management Responses; Vose, J.M., Peterson, D.L., Luce, C.H., Patel-Weynand, T., Eds.; Gen. Tech. Rep. WO-GTR-xx; U.S. Department of Agriculture, Forest Service: Washington, DC, USA, in press.

63. Farr, T.G.; Rosen, P.A.; Caro, E.; Crippen, R.; Duren, R.; Hensley, S.; Kobrick, M.; Paller, M.; Rodriguez, E.; Roth, L.; et al. The Shuttle Radar Topography Mission. Rev. Geophys. 2007, 45. [CrossRef]

64. Forsythe, W.C.; Rykiel, E.J.; Stahl, R.S.; Wu, H.-I.; Schoolfield, R.M. A model comparison for daylength as a function of latitude and day of year. Ecol. Model. 1995, 80, 87-95. [CrossRef]

65. Schaetzl, R.J.; Krist, F.J.J.; Miller, B.A. A taxonomically based ordinal estimate of soil productivity for landscape-scale analyses. Soil Sci. Soc. Am. J. 2012, 75, 1-8. [CrossRef]

66. Koch, F.H.; Smith, W.D.; Coulston, J.W. An Improved Method for Standardized Mapping of Drought Conditions. In Forest Health Monitoring: National Status, Trends, and Analysis 2010; Gen. Tech. Rep. SRS-GTR-176; Potter, K.M., Conkling, B.L., Eds.; U.S. Department of Agriculture Forest Service, Southern Research Station: Asheville, NC, USA, 2013; p. 164.

67. Liaw, A.; Wiener, M. Classification and regression by randomForest. $R$ News 2002, 2, 18-22.

68. R_Development_Core_Team. R: A Language and Environment for Statistical Computing. Version 3.1.1; R Foundation for Statistical Computing: Vienna, Austria, 2014.

69. Fry, J.A.; Xian, G.; Jin, S.; Dewitz, J.A.; Homer, C.G.; LIMIN, Y.; Barnes, C.A.; Herold, N.D.; Wickham, J.D. Completion of the 2006 national land cover database for the conterminous United States. Photogramm. Eng. Remote Sens. 2011, 77, 858-864.

70. Breiman, L. Random forests. Mach. Learn. 2001, 45, 5-32. [CrossRef]

71. Roy, M.-H.; Larocque, D. Robustness of random forests for regression. J. Nonparametric Stat. 2012, 24, 993-1006. [CrossRef]

72. Hagen-Zanker, A. Comparing Continuous Valued Raster Data: A Cross Disciplinary Literature Scan; Research Institute for Knowledge Systems: Bilthoven, The Netherlands, 2006.

73. Iverson, L.R.; Schwartz, M.W.; Prasad, A. How fast and far might tree species migrate under climate change in the eastern United States? Glob. Ecol. Biogeogr. 2004, 13, 209-219. [CrossRef]

74. Iverson, L.R.; Schwartz, M.W.; Prasad, A.M. Potential colonization of new available tree species habitat under climate change: An analysis for five eastern US species. Landsc. Ecol. 2004, 19, 787-799. [CrossRef]

75. Prasad, A.M.; Gardiner, J.; Iverson, L.; Matthews, S.; Peters, M. Exploring tree species colonization potentials using a spatially explicit simulation model: Implications for four oaks under climate change. Glob. Chang. Biol. 2013, 19, 2196-2208. [CrossRef]

76. Clark, J.; Iverson, L.; Woodall, C.W.; Allen, C.D.; Bell, D.M.; Bragg, D.C.; D'Amato, A.W.; Davis, F.W.; Hersh, M.H.; Ibanez, I.; et al. Impacts of increasing drought on forest dynamics, structure, diversity, and management. In Effects of Drought on Forests and Rangelands in the United States: A Comprehensive Science Synthesis; Vose, J., Clark, J., Luce, C., Patel-Weynand, T., Eds.; Gen. Tech. Rep. WO-93b; U.S. Department of Agriculture, Forest Service, Washington Office: Washington, DC, USA, 2016; pp. 59-96. 
77. Dukes, J.S.; Pontius, J.; Orwig, D.; Garnas, J.R.; Rodgers, V.L.; Brazee, N.; Cooke, B.; Theoharides, K.A.; Stange, E.E.; Harrington, R.; et al. Responses of insect pests, pathogens, and invasive plant species to climate change in the forests of northeastern North America: What can we predict? Can. J. For. Res. 2009, 39, 231-248. [CrossRef]

78. Fei, S.; Desprez, J.M.; Potter, K.M.; Jo, I.; Knott, J.A.; Oswalt, C.M. Divergence of species responses to climate change. Sci. Adv. 2017, 3, e1603055. [CrossRef] [PubMed]

79. Matthews, S.N.; Iverson, L.; Peters, M.; Prasad, A.M. Assessing Potential Climate Change Pressures Throughout This Century across the Conterminous United States: Mapping Plant Hardiness Zones, Heat Zones, Growing Degree Days, and Cumulative Drought Severity Throughout this Century Research Map NRS-9; U.S. Department of Agriculture, Forest Service. Northern Research Station: Newtown Square, PA, USA, 2018; p. 31.

80. Iverson, L.; Matthews, S.; Prasad, A.; Peters, M.; Yohe, G. Development of risk matrices for evaluating climatic change responses of forested habitats. Clim. Chang. 2012, 114, 231-243. [CrossRef]

81. Matthews, S.N.; Iverson, L.R.; Prasad, A.M.; Peters, M.P.; Rodewald, P.G. Modifying climate change habitat models using tree species-specific assessments of model uncertainty and life history-factors. For. Ecol. Manag. 2011, 262, 1460-1472. [CrossRef]

82. Box, G.; Draper, N.R. Empirical Model-Building and Response Surfaces; Wiley: New York, NY, USA, 1987.

(c) 2019 by the authors. Licensee MDPI, Basel, Switzerland. This article is an open access article distributed under the terms and conditions of the Creative Commons Attribution (CC BY) license (http:/ / creativecommons.org/licenses/by/4.0/). 